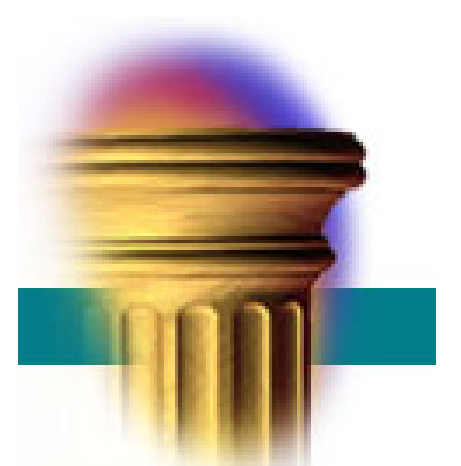

\title{
of \\ Central Clearing and Systemic Liquidity Risk
}

\author{
Thomas King, Travis D. Nesmith, \\ Anna Paulson, and Todd Prono
}

\section{December 2019}

WP 2019-12

https://doi.org/10.21033/wp-2019-12

${ }^{*}$ Working papers are not edited, and all opinions and errors are the responsibility of the author(s). The views expressed do not necessarily reflect the views of the Federal Reserve Bank of Chicago or the Federal Reserve System. 


\title{
CENTRAL CLEARING AND SYSTEMIC LIQUIDITY RISK
}

\author{
THOMAS KING, TRAVIS D. NESMITH, ANNA PAULSON, AND TODD PRONO
}

АвsтRACт. By stepping between bilateral counterparties, a central counterparty (CCP) transforms credit exposure. CCPs generally improve financial stability. Nevertheless, large CCPs are by nature concentrated and interconnected with major global banks. Moreover, although they mitigate credit risk, CCPs create liquidity risks, because they rely on participants to provide cash. Such requirements increase with both market volatility and default; consequently, CCP liquidity needs are inherently procyclical. This procyclicality makes it more challenging to assess CCP resilience in the rare event that one or more large financial institutions default. Liquidity-focused macroprudential stress tests could help to assess and manage this systemic liquidity risk.

KeYwords: Financial systems; Central counterparties; CCPs; margin; liquidity risk; systemic risk; financial stability; procyclicality

JEL: G23; G21; G28; E58; N22

\section{INTRODUCTION}

Central counterparties (CCPs) play a critical role in the financial system. A CCP, by inserting itself between the two participants in a securities or derivatives transaction, guarantees payments that could otherwise be jeopardized by the default of either participant. Central clearing has grown over the last several decades, both in absolute terms and relative to the size of financial markets. Some of this growth has been driven by market participants' recognition of the benefits of central clearing. Since the financial crisis, global regulatory efforts

We thank Ivana Ruffini Ruffini for her comments and for providing substantial insights into the data. We also thank Kelsey Burr, Marta Chaffee, Roy Cheruvelil, Josh Gallin, Richard Haynes, Mike Kiley, Beth Klee, David Li, Jennifer Lucier, David Murphy, Sam Schulhofer-Wohl and Jonathan Rose for helpful comments and feedback. Most of all, we want to recognize the debt we owe our former colleague Robert Cox; he not only influenced this paper with his comments, but more generally influenced our understanding of the topic. David Kelley, Tim Larach and John Spence provided excellent research assistance. The analysis and conclusions set forth are those of the authors and do not indicate concurrence by other members of the research staff, the Federal Reserve Bank of Chicago, the Board of Governors, or the Federal Reserve System. 
also contributed to the growth by mandating the clearing of certain over-the-counter (OTC) derivatives. By the first half of 2018 , over $75 \%$ of the notional value of interest rate swaps (IRS) and credit default swaps (CDS) - the two largest categories of OTC derivatives affected by clearing mandates-was centrally cleared. ${ }^{1}$

We review the central clearing landscape, focusing on the large CCPs that are most relevant for the US financial system and certain financial-stability issues related to CCPs more generally. At the outset, it is important to recognize that in most circumstances CCPs improve financial stability relative to a world in which trades are bilateral. ${ }^{2}$ There are a variety of ways in which they do so, including: by insulating members' from each others' defaults by stepping in between trades; by simplifying and reducing members' gross exposures through the netting of positions; by centralizing risk management within a small number of relatively transparent entities; and by pooling financial resources to address extreme tail risks. Ultimately, a CCP is intended to mitigate the impact of a default, on surviving counterparties and the broader market, by orderly liquidating a defaulting portfolio and covering losses with prefunded financial resources.

Situations in which CCPs reduce systemic risk due to reducing contagion potentially stemming from counterparty defaults have been studied recently by Duffie and Zhu (2011) and Amini et al. (2016), among several others. However, those papers are largely concerned with the potential for contagion as a result of CCPs being unable to meet their obligations following member default. We highlight a different problem: the ability of CCPs to fulfill their obligations in stressful periods involves their accessing contingent liquidity from members in a procyclical way. In other words, $\mathrm{CCP}$ resource demands are inherently procyclical with respect to market conditions. Our discussion generally connects back to Bernanke (1990), who, in the wake of the 1987 stock market crash, expressed concerns both about the limits to CCPs' ability to address systematic risks on their own and the potential for CCPs to be a source of risk.

The critical nature of the role played by CCPs was recently illustrated by the September 2018 default of a clearing member at the Swedish CCP, Nasdaq Clearing. Related losses ate through much of the CCP's prefunded buffer, and surviving members found themselves required to replenish $\$ 107$ million of that buffer within a few days. While some elements of this event were

${ }^{1}$ Clearing percentages calculated from Bank for International Settlements data at https://www.bis.org/ statistics/derstats.htm.

${ }^{2}$ For example, Kiff et al. (2010) argues that well-run CCPs reduce systemic risk, in principle. More recently, FSB (2017b, page 1) concludes that reforms have mitigated systemic risk in OTC derivatives largely because of increased central clearing. 
idiosyncratic, the default originated due the clearing member's inability to meet the CCPs' liquidity demands generated by extremely large movements in the spread between Nordic and German Power. The difficulties in liquidating the portfolio amid this market dislocation, and the resulting impact on other clearing members, illustrates the potential for liquidity problems at a CCP to amplify systemic risk.

Large CCPs are by nature concentrated and interconnected. Furthermore, their main counterparties are global systemically important banks (GSIBs), which are themselves key actors in the financial system. ${ }^{3}$ Barker et al. (2017) argue that banks' need to model their interconnected exposures to CCPs and that the modeling is extremely complex. CCPs are connected to and dependent upon GSIBs through a variety of channels in addition to direct clearing relationships. These channels include the obligation of banks to post margin to CCPs to cover changes in the market value and risk of their cleared positions, the contributions banks must make to CCP default funds both in anticipation of and subsequent to member defaults, and the provision of lines of credit and other liquidity arrangements by banks to CCPs. The timing of any CCP stress, therefore, has the potential to strain bank and dealer resources in environments in which those institutions are already under stress (Faruqui et al., 2018).

Although market participants are aware of the potential for procyclicality, and CCPs have devoted efforts to mitigating it, both prudence and regulatory directives lead CCPs to build stronger defenses during periods of greater realized and anticipated stress. Some element of procyclicality is an unavoidable consequence of such dynamic risk management (Maruyama and Cerezetti, 2019). CCPs are most critical precisely when systemic stress occurs, heightening concerns over whether or not CCPs' dynamic risk management sufficiently anticipates systemic stress. Under such stress, a CCP is intended to prevent fire sales and contagion by acting like a 'fire break' to stop the default of one financial institution from engulfing other institutions and even the cleared market. Faruqui et al. (2018) also consider how feedback loops between CCPs and banks can be destabilizing. Here, we focus more on the inherent procyclicality in CCP risk management and the implications for feedback vis-à-vis banks.

A key component of CCP risk management is margin: cash and collateral posted to the CCP to cover current and potential future exposures of clearing members and their clients. The procyclicality of margin requirements has been studied by Murphy et al. (2014) and Glasserman

${ }^{3}$ The FSB $(2017 \mathrm{a}, 2018 \mathrm{a})$ has detailed the high interconnectedness between the largest CCPs and eleven to twenty large financial institutions. 
and $\mathrm{Wu}(2018)$, and regulatory bodies have highlighted this procyclicality as a concern (e.g. CPMI-IOSCO $(2012,2016))$. But we are not aware of any studies that focus on the impact of this procyclicality on bank condition. ${ }^{4}$ Moreover, we emphasize the additional demands that CCPs may place on banks during stressful periods, beyond margin requirements. Most large banks have these multiple types of obligations toward multiple CCPs simultaneously. Some of these obligations are more likely to come due or to be larger during times of heightened market volatility and risk. These obligations have received very little attention in the literature even though, during severe crises, they could be substantial. The recent paper by Maruyama and Cerezetti (2019) notably studies the inherent procyclicality of CCP risk management, including some of the additional demands that banks could face, but does not focus as much on financial stability.

Our discussion of the procyclicality of potential CCP demands fits into a broader literature showing how synchronized liquidity needs in the financial sector can be destabilizing and lead to systemic risk. Adrian and Shin $(2008,2010)$ show that intermediaries broadly decrease leverage during periods of financial stress, and they argue that this behavior is indicative of procyclical liquidity in the financial system as a whole. More specifically, Allen et al. (2009), Acharya et al. (2010), and Heider et al. (2015) present models in which bank demand for liquidity is inefficiently high during crises, contributing to instability of the interbank market. Ashcraft et al. (2011), Acharya and Merrouche (2012), and Berrospide (2013) document that banks did indeed hoard liquidity during the 2008 financial crisis. ${ }^{5}$ These shifts in the demand for safe and liquid assets can cause financial institutions to fire-sale securities (Shleifer and Vishny, 2011, Greenwood et al., 2015) and reduce lending (Cornett et al., 2011, Iyer et al., 2014). In addition to creating instability within the financial sector, such disturbances can have real effects through the cost and availability of credit. The increasing contingent obligations of

${ }^{4}$ Duffie (2014) study how collateral demands shift with the introduction of mandatory margin and central clearing. Similarly, Heller and Vause (2012) show that the current set of rules can place significant liquidity burdens on clearing members, potentially contributing to their failure, and Gibson and Murawski (2013) study banks' trading behavior and welfare under different margin regimes. However, the analyses in these papers are static; they do not consider how liquidity demands vary over time with financial-market conditions. Sidanius and Zikes (2012) estimate that collateral demand from margin requirements (both in and out of CCPs) would be approximately twice as large under "stressed" market conditions as it is under "normal" conditions.

${ }^{5}$ Cornett et al. (2011) and Ippolito et al. (2016) emphasize that bank exposure to liquidity risk during stressful periods can come both from creditor demands and from off-balance- sheet commitments, such as lines of credit. While the ability of banks to provide liquidity on both sides of their balance sheets has traditionally been seen as a stabilizing force (Kashyap et al., 2002), this is only true to the extent that liquidity outflows are imperfectly correlated. Ivashina and Scharfstein (2010) show that draws on lines of credit occurred during the crisis at precisely the time that banks also faced difficulty rolling over their liabilities. 
banks to CCPs constitute an additional source of liquidity pressure-likely correlated with both asset and liability draws during stressful periods-adding to the funding pressures faced by banks during stress.

Similar effects extend outside of the commercial banking sector. In particular, liquidity shortages may affect broker-dealers' willingness to provide securities financing to clients. The procyclicality of balance sheets demonstrated by Adrian and Shin (2010) is suggestive of such activity, as it primarily reflects activity in the repo market, where most dealer financing takes place. In Brunnermeier (2009), increases in the collateral demanded by dealers for securities financing leads to asset-price volatility that feeds back into funding conditions in a destabilizing spiral. To the extent that dealers experience or anticipate extraordinary liquidity demands from CCPs, they may respond by making funding conditions more restrictive, increasing the likelihood of such a spiral.

Finally, the contingent obligations of banks to CCPs also have implications for system-wide liquidity measurement. For example, though potentially large, these commitments do not generally factor into measures of aggregate liquidity conditions that have been proposed in the academic literature (Berger and Bouwman, 2009, 2017, Bai et al., 2018). Consequently, as central clearing gains importance, such indices could provide overly sanguine views of banks' liquidity exposures. Similarly, most stress-testing implementations (e.g., those surveyed in Borio et al. (2014) and Schuermann (2014)) have paid little attention to potential coordinated liquidity exposures to CCPs.

Although individual CCPs regularly stress test the sufficiency of their own liquid resources, this "micro" approach is not designed to estimate the potential liquidity impacts across multiple CCPs at a time of financial stress. In addition to CCPs' own liquidity stress tests, the U.S. Commodity Futures Trading Commission (CFTC) and the European Securities and Markets Authority (ESMA) both have conducted liquidity stress testing using their own scenarios applied jointly to sets of CCPs (see CFTC (2017) and ESMA (2018a) respectively). Supervisors also have considered designing explicitly macroprudential stress scenarios; for example, see CPMI-IOSCO (2017) and Anderson et al. (2020). Such macroprudential stress tests could provide insights into potential aggregate liquidity demands in response to an extreme but plausible market event. At the end of this paper, we discuss some proposals for incorporating CCP liquidity into a macro stress-testing framework. Insights from such tests could be crucial 
in more accurately assessing whether CCPs and the broader financial system could weather any procyclical demands for liquidity emanating from central clearing.

Section 2 of this paper provides a brief overview of the U.S. CCP landscape and discusses how CCPs fit into the broader financial system. Section 3 reviews the basics of CCP operation and risk management. Section 4 discusses various ways that CCP risk management can extract liquidity from the rest of the financial system during times of financial stress. Section 5 describes the role of liquidity stress tests at both the CCP and macro-level. Section 6 concludes.

Throughout the paper, in addition to other data sources, we make use of new "quantitative disclosure" data on CCP operations, required by CPMI-IOSCO (2015). These quarterly data, which most large CCPs began reporting publicly in 2015, cover a variety of aspects of individual CCP operations and resources in a consistent manner. ${ }^{6}$

\section{The US CCP LANDSCAPE}

As cataloged by Kroszner (1999, 2000), CCPs developed in the US to address counterparty risks in response to financial crises. Indeed, the essential function of a CCP is transforming counterparty exposure. A CCP steps into each trade between its clearing members. Consequently, the original counterparties to the trade no longer face each other, but rather both face the central counterparty. By design, a CCP is a very restricted counterparty as it does not take any positions on its own behalf. By being the "buyer to every seller and seller to every buyer," a CCP always maintains a perfectly matched book and therefore takes no direct market risk in the markets it clears. However, the CCP is exposed to contingent market risk upon the default of a clearing member, because it acquires the defaulting member's positions. A CCP then has to take steps to return itself to a matched book and flat market-risk position. (We discuss CCP risk management in the next section.)

CCPs generally fared well, and served their role as a buffer against defaults, during the financial crisis. For example, from Valukas (2010), CME closed out the cleared derivatives portfolio of Lehman Brothers, which had a net value around \$21 billion in May 2008, within a few days using Lehman's margin resources; Lehman's margin was sufficient to cover auction-related losses amounting to $\$ 1.2$ billion. Similarly, at LCH SwapClear, Lehman's interest rate swap portfolio, with a notional value of $\$ 9$ trillion spread over 66390 trades across five currencies,

${ }^{6}$ See Alfranseder et al. (2018) for further discussion of this data and its usefulness for monitoring CCPs. We access the data through Clarus CCPView. 
was closed out by early October (LCH.Clearnet, 2008). However, as discussed in Fleming and Sarkar (2014) and Wiggins and Metrick (2019), central clearing faced some challenges and consequent criticism. Despite this stress, as shown in Figure 1 on page 26, the percentage of cleared IRS trades (the blue line) jumped from less than $25 \%$ in 2007 to nearly $50 \%$ by 2009 , as traders sought the safety of CCPs during the crisis. In 2009, the G-20 leaders committed to clearing all standardized OTC derivatives contracts through CCPs. The goal was to address risks in the bilateral OTC derivatives' markets, including large concentrations of counterparty exposures, inconsistent risk management, a scarcity of prefunded resources to cover realized losses, a lack of transparency, and adverse feedback loops (e.g., margin spirals). Subsequently, as shown in the figure, clearing of IRS rose to $75 \%$.

In the years since the crisis, a variety of factors have led to further increases clearing volumes for both exchange- traded and OTC derivatives. The most direct impetus was the establishment of central clearing mandates for OTC derivatives noted above. ${ }^{7}$ In Figure 1, for example, the jump in cleared interest-rate swaps from about $50 \%$ in 2012 to near $75 \%$ by 2014 is coincident with mandates coming into force. Similarly, CDS clearing, which began at ICC (formerly ICE Trust) in March 2009 and at ICE Clear Europe (ICEU) in July 2009, has steadily climbed to nearly $40 \%$ by 2017 according to BIS data (not shown in the figure). ${ }^{8}$ This increase came despite delays in implementing clearing mandates. For both IRS and CDS, over $80 \%$ of new dollar- denominated trades are centrally cleared. Some of the growth in central clearing likely reflects an increased appreciation for the risk-mitigating function of CCPs following the crisis. It also likely reflects a variety of market moves away from more exotic and bespoke trades to more standardized ones. The increased clearing rate means that clearing volumes have held roughly steady even as notional amounts fell by a third in the last few years. More recent support for central clearing has been provided by bilateral margin requirements; (FSB, 2018b) found that OTC derivative clearing dramatically accelerated in terms of notional cleared upon the implementation of bilateral margin requirements, even for trades where central clearing was not required.

Today, six CCPs clear the most important U.S. financial markets; these are listed in Figure 2. Five of these CCPs are designated as systemically important in the US. The sixth,

7Culp (2010) reviews the regulatory history of OTC derivatives' clearing through the Dodd-Frank legislation. FSB (2018b) analyzed the incentives to centrally clear created by various reforms beyond just clearing mandates.

${ }^{8} \mathrm{CME}$ also started clearing CDS in 2009, but terminated the service in early 2018. 
London Clearing House (LCH) SwapClear, is a UK CCP but clears a substantial amount of US dollar-denominated interest rate swaps. These six CCPs can be classified as clearing securities and derivatives, respectively. The securities CCPs include the Fixed Income Clearing Corporation (FICC), which operates two separate clearing services: one for US Treasuries and repurchase agreements (repos), and one for mortgage-backed securities (MBS). The National Securities Clearing Corporation (NSCC) also clears securities; it is the primary clearer for US equity markets, and also clears corporate and municipal bonds. These securities CCPs are all part of the Depository Trust Clearing Corporation. Derivatives CCPs include: the Options Clearing Corporation (OCC), which is the primary clearer for US equity options; the Chicago Mercantile Exchange Inc. (CME), which operates two separate clearing services, one for futures and options, and one for interest rate swaps (IRS) and swaptions; ICE Clear Credit (ICC), which clears credit default swap (CDS) indexes and single names; and, LCH SwapClear, which also clears IRS. Derivatives CCPs can further be divided by whether the cleared derivatives are exchange-traded or OTC. OCC and CME's Base service clear exchange-traded derivatives. The remainder-CME's IRS service, ICC, and LCH SwapClear-clear OTC derivatives. ${ }^{9}$

Measuring the size of CCPs is not entirely straightforward, but Figure 2 provides some context. The next-to-last column on the right presents recent approximate total prefunded resources and the last column presents the maximum daily call for margin since 2015. Clearly, all the CCPs have significant resources available, but also all have made significant calls for additional funds from the market. It should be noted that the measures of size used here likely understate the economic impact of securities clearing houses, because they do not capture the total cash that flows through securities CCPs, which is substantial due to the settlement demands for cash.

\section{CCP Function and Risk Management}

The concentration of counterparty exposure at a CCP means the success, or failure, of its risk management controls to manage potential contagion could have profound implications for the

9Under the Dodd-Frank legislation, the Securities and Exchange Commission (SEC) is the Supervisory Agency for FICC, NSCC, and OCC while the CFTC is the Supervisory Agency for CME and ICC. Because ICC is registered with the SEC as a clearing agency, the SEC also has authority over all of its clearing services. The Federal Reserve has authority to participate in the designated supervisor's examinations and reviews of material changes at the designated CCPs. LCH Swapclear is registered with, and supervised by, the CFTC for the clearing of US dollar denominated positions; The Federal Reserve also participates in international oversight of LCH Swapclear under the auspices of the Bank of England. 
markets it clears. Success means defaults are not amplified with potential systemic implications; failure, although designed to be an extremely remote possibility, potentially creates contagion effects between clearing members that would not otherwise have been exposed to the default. CCPs manage their credit and liquidity risks differently than banks, partly reflecting that CCPs do not actively trade financial contracts, but rather manage the risks generated by participants trading activity. ${ }^{10}$

CCP risk management generally includes membership eligibility requirements, the netting of exposures, margin requirements, mutualized financial resources usually in a default or guaranty fund, and default-management procedures. See Murphy (2013) for a fuller discussion. CCPs may also have additional tools to employ in recovery scenarios, such as assessment powers, variation margin haircutting, contract tear-ups, or loss allocation powers (CPMI-IOSCO, 2014, Sec. 4). In addition to the management of credit risk, CCPs also manage liquidity risk, and have a variety of tools to address liquidity needs, such as access to collateral markets and pre-arranged repo lines. With an eye towards the subsequent discussion of procyclicality, we review two of the most important elements of CCP risk management: margin and mutualized financial resources, which represent pre-funded resources held by the CCP. Both resources are critical to managing and mitigating a CCP's contingent risk exposures and are two major drivers of procyclicality in CCPs' resource demands.

Margin is a critical component of CCP risk management. It can be divided into variation margin (VM) and initial margin (IM); Figure 3 illustrates how VM extinguishes a CCP's current exposure and IM covers potential future exposure. We discuss each type of margin in turn.

Variation margin covers the realized change in a cleared position. Regulations generally require CCPs to collect and pay out in cash the daily change in value that each member's portfolio experiences as VM. ${ }^{11}$ In the stylized example in Figure 3, the change in value of the portfolio at the end of the day is negative. The clearing member must pay this amount to the CCP. The total value of the payments of VM exactly equals the amount owed to clearing members whose portfolios gained in value. By marking every portfolio to market daily and

\footnotetext{
${ }^{10}$ In the event of a clearing member default, a CCP may trade in order to hedge and liquidate the defaulter's portfolio, but usually needs to secund traders from its clearing members to do so. For further discussion of the differences between banks and CCPs, particularly the different roles played by capital and collateral in their respective risk management approaches, see Manning and Hughes (2016) and Cox and Steigerwald (2018)

${ }^{11}$ There are exceptions. In particular, FICC's clearing structure for mortgage-backed securities collects VM, but does not pass it through. OCC collects little VM, because the covered options positions it clears are generally hedged by the underlying securities.
} 
exchanging cash to cover the changes, the CCP resets its current exposure to zero every day and prevents exposures from accumulating. ${ }^{12}$ The requirement to pay VM, however, also creates a point of failure; if a clearing member fails to make a VM payment for itself or its clients in the time required, the $\mathrm{CCP}$ can, and likely will, declare the clearing member to be in default. ${ }^{13}$ As emphasized by Maruyama and Cerezetti (2019), VM is the main driver of CCP margin calls. The requirement to meet VM effectively tests the clearing member's performance at least daily, which in some sense transforms the credit exposure it faced with its original counterparty to a liquidity exposure to the CCP (Cont, 2017).

Initial margin is designed to cover the potential future exposure of a clearing member's portfolio from the time of the last VM payment until the portfolio could be liquidated in a default. Because the loss that could be realized on a portfolio is uncertain, IM targets a high quantile—at least the 99th percentile—of market moves over the specified close-out period (also sometimes called the margin period of risk). In Figure 3, IM covers both the VM that was not paid during a default plus additional losses on the position that could be realized during the close-out. At their core, CCPs' IM estimates for a portfolio bear similarities to standard market risk calculations, like value-at-risk or expected shortfall. However, regulatory requirements also specify that IM covers other exposures that are more difficult to quantify, like estimates of portfolio transaction costs, jump-to-default exposures, and concentration risks. CCPs also often include anti-procyclical elements in their margin calculations. Heckinger et al. (2017) review both historical and current IM practices. Looking across certain derivatives CCPs for futures and swaps, as shown in Figure 4 the size of IM requirements has more than doubled from less than $\$ 194$ billion at the end of 2013 to over $\$ 425$ billion in August, 2019. ${ }^{14}$ This growth in IM also implies commensurate growth in the amount of risk CCPs are managing.

To cover potential losses beyond margin in the event of a default, CCPs require clearing members to provide mutualized financial resources sufficient to meet a specific coverage target in a wide range of extreme but plausible stress scenarios. The mutualized resources are sized so that the CCP has sufficient financial resources to cover the default of either any single or any

\footnotetext{
${ }^{12}$ In addition, VM is sometimes exchanged intra-daily to more actively limit the buildup of current exposures that might occur more rapidly, for example, in more volatile markets.

${ }^{13}$ Armakolla and Laurent (2017) shows the importance of members' abilities to meet their obligations for the resilience of a CCP.

${ }^{14}$ The data includes requirements from more than the systemically important CCPs. Besides ICEU, which clears energy futures and options in addition to CDS, and other parts of LCH Ltd. besides SwapClear, requirements from ICE US, which clears a variety of futures and options, and LCH SA, which is the European sited counterpart to LCH Ltd. in the UK are included.
} 
pair of clearing members in stressed market conditions. ${ }^{15}$ At most CCPs, mutualized resources are maintained in a separate fund, called a default or guaranty fund. The US securities CCPs instead mutualize all IM. In either case, the adequacy of these resources is tested daily by the $\mathrm{CCP}$ through its stress-testing program, which is required to apply a variety of extreme but plausible scenarios: both historically observed market stresses and hypothetical scenarios.

To cover any losses from a default, a CCP would use prefunded resources in a prescribed sequence, often called the CCP “waterfall." The defaulter's margin absorbs losses first. If the defaulter's margin is exhausted, any additional resources provided by the defaulting party, such as its contributions to a default fund, are applied. If the defaulter's resources are exhausted, before mutualizing losses to surviving clearing members, CCPs typically apply a portion of their own capital—known as "skin-in-the-game" — to cover remaining losses. Mutualized resources would be applied to any remaining losses. CCPs are required to have explicit rules and procedures that address how potentially uncovered credit losses would be allocated. They may also have additional prescribed assessment powers to seek further resources from non-defaulting members.

The strong and consistent risk management practices adopted by CCPs have been enhanced by stronger regulatory expectations promulgated in the wake of the crisis. This strengthening was facilitated by the development of internationally-agreed risk-management standards set out in the "Principles for Financial Market Infrastructures" (PFMI). ${ }^{16}$ The principles in the PFMI set several expectations for CCPs, including effectively managing all dimensions of its credit and liquidity risks, employing a robust margining system, and maintaining a minimum level of financial resources to cover potential losses and honor payment obligations, both in extreme market conditions. The principles are designed to ensure that CCPs will halt contagion among their members and mitigate systemic risk across the interconnections.

\section{Potential Procyclical Resource Demand}

Any reduction in systemic risk afforded by central clearing depends on CCPs performing as designed in stressed markets. As noted above, CCPs have grown both in size and in the scope of the products they clear. Furthermore, individual systemically important banks tend to

\footnotetext{
${ }^{15}$ Specifically, in the US, FICC, NSCC and OCC are required to cover the single largest default loss, while CME and ICC are required to cover the largest two default losses, as is LCH SwapClear.

${ }^{16}$ See CPMI-IOSCO (2012).
} 
participate in multiple CCPs, in order to access different markets across different jurisdictions. For example, the recent analysis in FSB (2018a) shows that out of a set of 26 major global CCPs, the 11 largest clearing members in terms of aggregate resources are members of at least 16 of the 26 with a median participation of 22. Many of these same large financial institutions also provide other services to CCPs, such as settlement and investment services and lines of credit. This interconnectedness, together with CCPs' critical functions supporting markets, naturally raises the need to monitor their impact on financial stability.

CCPs' risk-management controls can affect the financial institutions expected to meet one or more resource demands, particularly if resource demands come at times of heightened financial stress. These resources include: (1) variation margin; (2) initial margin; (3) settlement requirements; (4) default fund contributions and assessments; (5) lines of credit and other liquidity arrangements; and (6) capital and liquidity to absorb the positions of members and their clients in the event of default. In this section, we review each of these potential resource demands in turn.

From a systemic-risk perspective, there is a trade-off between rigorously managing the risk of positions cleared through CCPs and minimizing liquidity strains on the system. The failure of a large CCP would be a devastating event for the global financial system-one that would likely be accompanied by massive disruptions in financial markets and the severe distress or failure of many other systemically important institutions. From a financial- stability perspective, it is important for CCPs to maintain financial resources sized to cover potential losses in a wide range of stress scenarios. One hypothetical way to achieve this would be for CCPs to prefund all of these financial resources ex ante by holding very large quantities of safe and liquid assets at all times. Such an approach would tie up liquidity and collateral in accounts that, most of the time, would be well in excess of any plausible loss that the CCP might experience. Moreover, the requirement to keep large amounts of assets parked at CCPs continuously would impose costs on clearing members; those costs could well induce banks and their clients to move activity into uncleared positions (eliminating the stability benefits of central clearing) or to exit positions altogether, which could result in less hedging activity and a reduction in overall market liquidity. Rather than holding all of the financial resources required to address potential losses in a range of stress scenarios all the time, CCPs hold smaller (though still significant) 
amounts of liquid resources during calm periods and increase these resources during times of high financial market volatility, when they face the greatest threats.

Importantly, the most common resource draws that come from CCPs, margin calls, are not unique to clearing relationships. Prior to implementation of the Dodd-Frank Act (and similar regulatory changes abroad) many bank arrangements with non-bank counterparties included provisions for IM, and for most derivative exposures there was some periodic exchange of VM. However, these arrangements were somewhat ad hoc and flexible. With central clearing, margin requirements are universal for cleared contracts and, to a large degree, standardized due to consistent regulatory expectations. ${ }^{17}$

Nevertheless, because clearing takes place through a small number of CCPs, the models and rules used by any one CCP can have significant implications for a large number of market participants. In addition, much of the activity at CCPs is concentrated in a few large members. The concentration is illustrated in Figure 5, which shows that the five largest clearing members also account for the majority of IM requirements facing clients for both dollar-denominated clearing of both futures and swaps; in fact, at one point the five largest clearing members accounted for nearly three-quarters of clients' swap IM requirements, before declining to around $60 \%$. The concentration associated with CCPs and their large members imply that margin calls are likely to come in a more coordinated manner in a world with central clearing. Furthermore, as discussed below, CCPs also impose other types of obligations on their clearing members-obligations that have no counterparts in bilateral trading-and these are likely to be triggered in the same states of the world in which margin calls are large.

4.1. Variation margin. As noted earlier, $\mathrm{VM}$ is the amount that a clearing member must post to the CCP to cover marked-to- market changes in the value of its portfolio. Maruyama and Cerezetti (2019) illustrate how VM is the margin component that is most sensitive to market volatility. Because changes are greatest on days when market prices move most, the amount of VM paid to CCPs necessarily increases during times of high realized volatility in financial markets. Figure 6 illustrates this relationship by showing the peak amount of VM collected in each quarter by the CCPs through which U.S. banks clear most of their trades. This margin is plotted against the peak in the realized volatility of the stock market in each quarter. (Although

${ }^{17}$ Margin requirements, both for VM and IM, have also been established for bilateral trades (BCBS-IOSCO, 2015); for analysis of their impact on the incentives to centrally clear, see FSB (2018b). 
the data do not tell us for certain, it is likely that the peaks in the two series occur on the same days of each quarter.) This comparison is crude because some CCPs do not clear products that are directly linked to equity markets. Nevertheless, the tendency of volatility in most markets to move together makes the comparison informative, and the pattern is clear.

To meet VM calls, clearing members must make payments to the CCP in a short amount of time, often in as little as one hour, and these payments generally are made in cash. Furthermore, although clearing members who clear on behalf of clients pass through VM calls on client positions, this pass-through sometimes does not occur until the following day, and the clearing member is itself responsible for ensuring that the proper amount of margin is posted to cover the clients' losses. Clearing members and their clients expect to make (or receive) VM daily; however, because they reflect changes in asset prices, the size of VM calls are essentially unpredictable. To address this risk, clearing members maintain reserves of cash or have access to funding markets that can be drawn on with very short notice.

Even in times when financial institutions are not under severe pressure, VM calls due to spikes in volatility can be burdensome. Events surrounding the "Brexit" referendum in the U.K. in June 2016 provide an example. The referendum, the result of which surprised many, caused a spate of volatility in financial markets, particularly those involving the British pound, the euro, and associated fixed-income products. $\mathrm{LCH}$, which clears many such instruments, called for large amounts of VM in the wake of this episode. Figure 7 shows that on the peak day during the second quarter of 2016, VM payments to LCH totaled \$16 billion, in contrast to the daily average of about $\$ 3$ billion. These calls came simultaneously with smaller VM calls from other CCPs-CFTC (2016) found that LCH together with four other CCPs called for \$27 billion over the two days following the referendum. ${ }^{18}$

Under most circumstances, VM payments to CCPs do not reduce aggregate liquid resources available to market participants, because CCPs run matched books, so that every marked-tomarket gain they face is accompanied by an equal marked-to-market loss. Thus, VM ought to be passed through, dollar for dollar, from one set of clearing members (those with net losses) to another (those with net gains). Even so, the transfer of funds can cause stress for those with

\footnotetext{
${ }^{18} \mathrm{LCH}$ was also slower to make payments to members with position gains than it was to collect from members with losses, creating further liquidity pressure; some market participants seemed to find the obligation to post this margin onerous, despite the fact that the financial system itself did not appear to be under a particularly high level of pressure (Madigan et al., 2016).
} 
unanticipated liquidity outflows. Furthermore, particularly in times of stress, disruptions and delays in payment chains can occur, potentially preventing the liquid assets from flowing to their recipients in a timely manner. CCPs and settlement banks themselves may deliberately slow the transfer of liquidity out of a fear that their own liquid resources may prove inadequate. The stock-market crash of 1987 , for example, was accompanied by a number of disruptions in the payments system, including the reluctance of settlement banks to provide large amounts of intraday credit. As a result, VM payments to clearing members at CME and OCC were delayed, adding to the stress of market participants on an already volatile day (Presidential Task Force on Market Mechanisms, 1988).

Finally, extreme episodes of financial stress may also prevent clearing members from receiving the full VM due to them. In particular, if a CCP's resources should be exhausted by clearing member defaults, one option the CCPs has to manage liquidity is to "haircut" the VM it pays out. In this case, the CCP absorbs, at least temporarily, part of the VM it receives on loss positions. In such situations, the CCP may also pay out VM in securities collateral, rather than cash, putting the burden of liquidity transformation on members.

4.2. Initial margin. Initial margin is posted to CCPs to account for possible deterioration in the value of clearing member positions that might occur between the time of a default and the time the defaulting member's positions can be liquidated. Like VM, IM generally increases during times of financial-market volatility. As discussed in Murphy et al. (2014), the requirements to cover a quantile of market moves requires IM models to be risk-sensitive, and therefore procyclical, to at least some degree. However, while the pass-through of volatility to VM is largely mechanical and out of the CCP's control, the factors determining IM are more complex and depend on the specific practices the $\mathrm{CCP}$ follows. These practices are largely spelled out in CCP rulebooks, but they also involve elements of discretion.

As a baseline, CCPs maintain models of the value that positions could lose with some confidence-typically, $99 \%$ or $99.5 \%$ over a specified liquidation period (typically a few days). These tail losses are almost always greater when market volatility is expected to be higher, and consequently IM tends to increase in periods of high realized and implied volatility. As an example, Figure 8 plots the amount of IM that CME has required on an S\&P 500 futures contract, as a percentage of the contract value with the VIX index of implied volatility on the S\&P. It is clear that these two series move closely together. The strength of this relationship is 
further shown in Figure 9, which plots the same data against each other; the significant positive relationship can be seen by the slope of the regression line. ${ }^{19}$

As another example of the connection between volatility and IM, Figure 10 shows peak IM calls at the OCC, which primarily clears equity options; the jumps in equity volatility that occurred in February 2018 and December 2018 are clearly identified as causing corresponding jumps in IM during the relevant quarters.

Although it is related to volatility, the total amount of IM required of a clearing member is, in most cases, more complicated than the direct relationships suggested by Figures 8 to 10 . The net positions that clearing members and their clients maintain with CCPs consist of large arrays of financial instruments that are exposed to different types of risk. CCP margin models attempt to account for the comovement of different assets and employ a variety of modeling techniques to capture the tails of the joint distributions of returns. In addition, the overall level of margin charged often includes certain "add-ons," which tend to be less sensitive (to varying degrees) to market volatility (CPMI-IOSCO, 2016). And, of course, the total amount of IM required rises and falls with the size of participants' positions. Figure 11 shows quarterly changes in the total quantity of IM required by the major US CCPs, plotted against contemporaneous changes in the VIX. Although the figure suggests a correlation between volatility and IM, that correlation appears muted relative to the one between volatility and VM. Potential explanations for this dampened relationship include the anti-procyclicality tools that have been introduced; ESMA (2018b) codifies some anti-procyclicality tools, which have also been applied to US CCPs due to their global activity. Examples of tools include a buffer that allows for a proportion of margin to be temporarily exhausted following a significant increase in margin requirements lessens the size of any IM calls that result from sudden spikes in volatility, while a floor limits the amount that margin requirements can decline during tranquil periods, thereby muting the liquidity demands that result when tranquility gives way to turbulence.

Another reason that CCP IM requirements may not be direct functions of market volatility is that CCPs may attach margin surcharges to particular clearing members to compensate for concentration or counterparty risk. Though counterparty-risk surcharges are rare, they can result in sudden large increases in the amount of IM margin required from financial institutions that are already in distress. For example, as discussed by Heckinger (2014), amid concerns

\footnotetext{
${ }^{19}$ The line is calculated by an M-type estimator with Huber's T norm (Huber, 1981) to make the regression robust against the large positive outliers.
} 
about the risk associated with its repo positions, the futures commission merchant MF Global was downgraded by Moody's and Standard \& Poors on the week of October 24, 2011. Over the following few days, $\mathrm{LCH}$ (through which these repo positions were cleared) imposed counterparty-risk surcharges that approximately doubled the IM that MF Global was required to hold. The resulting margin calls, which totaled over \$50o million, exceeded MF Global's resources, which led directly to its failure. This sort of example illustrates how margin requirements can contain a pro-cyclical element, even if they are not explicitly tied to asset price volatility. $^{20}$

Finally, it is not only the amount of IM required that is likely to rise during times of market stress. According to the quantitative disclosure data, approximately half of IM is in the form of securities, rather than cash, and those securities are subject to haircuts. Lewandowska and Glaser (2017) find that one major CCP does not significantly increase its haircuts during times of market stress. Nevertheless, in principle, rising haircuts and declines in market value that could be associated with episodes of market volatility could lead to changes in haircuts and would require the posting of additional collateral even if the margin requirement were unchanged.

4.3. Settlement requirements. In discussing how VM and IM can vary with market volatility, there is a tendency to focus on the change in market prices. However, market volatility usually also is associated with increased trading activity. As a result, portfolio valuations can change because both prices and positions fluctuate. Importantly, increases in trading activity directly create liquidity needs at securities CCPs in order to settle the trades. Because the cash needed to settle securities corresponds directly to the full value of the securities trades, the resulting liquidity needs can be simultaneously material and procyclical. In terms of materiality, from the latest quantitative disclosures, the sum of the peak payment obligations in the prior twelve months was over $\$ 132$ billion. For derivatives, most trades do not require up-front payments to settle, so the effect there is at most minor. ${ }^{21}$ From a systemic view, the liquidity needs generated

${ }^{20}$ Standards require IM models to incorporate anti-procyclicality measures (CPMI-IOSCO, 2012), but ultimately IM will respond to changing risk exposures. Houllier and Murphy (2017), Wong and Pei (2017), and Glasserman and $\mathrm{Wu}(2018)$ study the problem of reducing margin procyclicality. O'Neill and Vause (2016) study how a time-varying "macroprudential buffer" added to IM can address fire-sale externalities. Raykov (2012) examines the trade-offs inherent in reducing the procyclicality of IM and finds that reducing it does not necessarily reduce systemic risk. ${ }^{21}$ Derivatives contracts can have settlement requirements, such as if an option is exercised or a future matures, but such requirements likely are not strongly procyclical. CDS potentially can generate procyclical payments due to the defaults of reference entities, but such payments are difficult to predict or regularly observe. 
by the settlement of centrally-cleared securities need to be combined with the liquidity needs from VM and IM in assessing the resiliency of the clearing system overall.

4.4. Default fund contributions and assessments. While VM and IM calls are the most common ways in which CCPs draw in resources from their clearing members, several other contingent relationships can also come into play, particularly in times of financial stress. One important way in which CCPs can require resources from their members is by calling for contributions to the default fund. Figure 12 shows the average quarterly changes in default fund sizes per clearing member split into the five largest versus the remaining. ${ }^{22}$ Since 2015, changes in average changes in default fund contributions have been small on average, however the average of averages masks volatility, particularly for larger clearing members, where even the quarterly average across the CCPs has been over $\$ 100$ million. The largest call at an individual CCP was over $\$ 540$ million and even clearing members not among the five largest faced a call of nearly $\$ 160$ million. Although likely less sensitive than margin, default funds can change due to changing portfolios, market risk, and risk management practices. In particular, sharper increases in market risk than observed in the data could generate more substantial calls for default fund resources.

There are three distinct circumstances under which CCPs may call on clearing members to add resources to the default fund. The first is intra-month calls for contributions in response to changes in risk that the CCP perceives. Typically, CCPs levy default-fund assessments monthly to reflect changes in market conditions and concentration that occur over the course of any given month. In times of market stress, however, CCPs may not wait for the end of the month. Intra-month default fund calls may be issued following sudden changes in market volatility. ${ }^{23}$

The second situation in which unscheduled payments to the default fund may occur is when a clearing member defaults and that member's IM and own default-fund contribution is insufficient to cover the liquidation value of its position. An example occurred in 2013 when a topping-up of the default fund was required at the Korean CCP KRX following a trading error that resulted in a clearing member losing $\$ 45$ million before a margin call could be issued. A more recent example is the 2018 default of a large clearing member at Nasdaq Clearing mentioned in the Introduction, which ultimately consumed approximately two-thirds of the

\footnotetext{
${ }^{22}$ This figure only includes the derivatives CCPs as the securities CCPs do not have clearing funds that are distinct from IM.

${ }^{23}$ Increased default fund needs could alternatively be addressed by issuing margin calls.
} 
mutualized default fund resources. Although both of these defaults were idiosyncratic and occurred during times of relative market calm, the obligation to replenish the default fund is a source of procyclicality, because both the likelihood of defaults and the potential impact of a realized default increase during times of market stress, when the necessary capital may be scarce. Because clearing member defaults that are large enough to breach a CCP's mutualized default resources are quite uncommon, there is also a risk that market participants may not be attuned to or prepared for the resource demands such defaults could generate. In addition, and from the perspective of a given clearing member, there is a distinction between the risks posed by VM and IM calls relative to calls for additional mutualized default fund resources, regardless of either the frequency or size of the associated calls, since the former two relate entirely to the portfolio that a given $\mathrm{CM}$ brings to the clearing house, while the latter, to a degree, depends upon the portfolios brought by other CMs, which are outside of the given CM's immediate control.

Finally, CCPs have powers of assessment in the event that the prefunded portion of the default fund is exhausted. Figure 13 shows the unfunded commitments that clearing members have to CCPs in such circumstances as a percentage of total default resources excluding IM. The exercise by a CCP of its unfunded commitments is a very rare situation, since prefunded resources are calibrated to cover the losses of a CCP's single or two largest clearing members. Thus, in principle, CCPs should only need to draw on unfunded commitments in cases in which three or more members default nearly simultaneously and have insufficient margin to make up for the loss associated with their positions. The caveat "in principle" reflects that one or two member defaults also could exhaust prefunded resources if the CCP's models are inaccurate or if liquidation of defaulted positions proves unexpectedly challenging. Clearly, an environment in which those defaults occurred would be associated with very high levels of market stress and liquidity demand and could strain clearing members' ability to meet their payment obligations.

4.5. Absorbing defaulting member positions. In the event of a clearing member default, the remaining clearing members may also have other obligations. In particular, they may acquire some or all of the defaulting member's positions and may also become responsible for the positions of the defaulting member's client. As part of its default-management procedures, an OTC derivatives CCP would typically auction part or all of the defaulting member's house 
portfolio. Depending on the rules of the $\mathrm{CCP}$, surviving clearing members may be obligated to participate in the auction. In addition, the positions of the defaulting member's clients must be transferred to remaining clearing members or be liquidated. Many market participants who clear indirectly have established backup relationships with one or more direct clearing members that they could activate in the event of the default of their primary clearer.

Absorbing this additional business places an added burden on clearing members' resources. In particular, clearing members that are banks or broker dealers are required to hold capital against both their own positions and those of their clients. Although institution-level data on house positions are not available, Figure 14 shows the size of the largest client positions at any clearing member, relative to the excess capital at the remaining clearing members. (The data are from the CFTC and only cover the derivatives CCPs.) "Excess capital" represents the amount of capital that clearing members have available to support additional positions. Thus, the ratio in the graph is a measure of members' ability to absorb the client business of another member. The ratio has been subdued in recent years, partly reflecting the high levels of capital in the banking sector, but it is not difficult to imagine it rising quickly during a banking crisis if capital becomes more scarce.

We note that, unlike many of the other procyclical resource demands noted in this paper, the need for banks to absorb house and client positions of defaulting members is largely an issue of capital. However, during stressful periods, capital and liquidity adequacy can become intertwined. Moreover, the absorption of new positions also requires bank liquidity, because it requires posting additional contributions to $\mathrm{CCP}$ default funds and reserving additional liquidity buffers to meet future margin calls. Again, given that at least one member has defaulted, these commitments are likely to occur in a time when the capital and liquidity of other members are already stretched thin. Furthermore, adding new positions and posting new collateral can impact regulatory liquidity ratio requirements. Even if not binding, a bank's willingness to absorb positions could be influenced by concerns over negatively impacting its liquidity ratio, which could be reflected in its valuation of the defaulted portfolio. ${ }^{24}$

${ }^{24}$ These concerns motivated in part the recent announcement of a revision to the treatment of client margin in calculating the liquidity coverage ratio (BCBS, 2019). 
4.6. Liquidity provision. Finally, CCPs maintain liquidity arrangements with many large banks. These arrangements include committed lines of credit, repo facilities, and foreignexchange swap agreements. Ideally, the counterparties on the other side of these contracts are liquidity providers that do not face the $\mathrm{CCP}$ in other types of transactions. In practice, most of the institutions that are in a position to commit to providing significant liquidity are large banks that also participate directly in CCPs, clearing high volumes of derivatives and securities transactions. Consequently, since large banks tend to be members of multiple CCPs and offer liquidity services to each, the supply of these services to the overall system of CCPs tends to be concentrated. FSB (2018a) reported that 27 percent of clearing members surveyed across $26 \mathrm{CCPs}$ also provide credit lines that provide liquidity to the CCP. Many of these clearing members provide such lines to multiple CCPs. ${ }^{25}$

Figure 15 shows total committed lines of credit and repo arrangements at CCPs as a fraction of the holdings of cash and cash plus liquid securities at large US banks. ${ }^{26}$ Although not all of the CCP liquidity providers are large US banks, the comparison nonetheless shows that, if these facilities were suddenly and significantly drawn upon, the cash demand could be significant. Furthermore, the significance is rising particularly relative to cash holdings, both because CCPs continue to improve their access to liquidity and as banks reduce cash holdings. Even if banks were able to meet this demand, doing so could well put pressure on short-term funding markets, including the interbank market and the repo market for high-quality collateral. Again, the CCPs are only likely to need to access their liquidity arrangements following the default of a very large clearing member, so it is probable that funding markets would already be under some pressure in such a situation. For example, CCPs would also most likely be withdrawing large sums from their cash deposit accounts at banks in such a situation.

4.7. The importance of CCP incentives. Although their procedures are governed by detailed rulebooks, CCPs retain some discretion in the extent and timing of their calls for resources. Two examples will illustrate this point.

\footnotetext{
${ }^{25}$ In the event of default, liquidity demands may be particularly large at the two securities CCPs, because such CCPs guarantee settlement of the full purchase price of securities. (The settlement value of derivatives contracts is typically a small fraction of their notional value.) For example, in the few days following the bankruptcy of Lehman Brothers in 2008, NSCC and FICC settled (without loss) over \$30o billion of securities transactions that Lehman had executed with its customers and other counterparties. In contrast, the market value of Lehman's obligations under derivative contracts was about $\$ 45$ billion (Valukas, 2010).

${ }^{26}$ Large banks includes those with over $\$ \mathbf{2 5 0}$ billion in assets.
} 
Bignon and Vuillemey (2018) describe one of the very few failures of a CCP, the Caisse de Liquidation des Affairesen Marchandises in Paris. In 1974, following a collapse of sugar prices, the CCP faced the default of a clearing member that had cleared a large volume of sugar futures. Because the CCP's margining practices were inadequate, the default would have created a loss for the CCP's members, but would have allowed it to continue operating. Instead, the CCP engaged in risk-shifting: it delayed declaring the underwater member in default, apparently in the hopes that its position would right itself. Instead, further losses accrued, eventually resulting in a shortfall so large that the CCP was forced to shut down.

More recently, Heckinger (2014) describes how, prior to the failure of MF Global in 2011, at least two CCPs (ICE Clear US and FICC) refused to release margin, totaling about \$10o million, that was due to the teetering broker-dealer. The CCPs may have feared that MF Global might subsequently take losses on positions cleared through them and not be able to make up the shortfall. Although these actions afforded the CCPs an additional layer of protection, they contributed to MF Global's liquidity shortfalls and ultimate demise.

As illustrated by these episodes and others noted above, CCPs can bend or circumvent rules, at least for a time, when it is in their interest to do so. Moreover, there is no guarantee that the interests of CCP owners will align with the advancement of financial stability. Some CCPs are owned by their members or exchanges, while others are owned by publicly traded companies. The ability of these owners to exercise discretion makes it important to consider the incentives that CCPs might face in stress situations. The CCPs discussed herein all have their own capital exposed in their default waterfalls. Being exposed to loss provides CCPs an incentive to manage risks, but could also incentivize defensive moves, like choosing to withhold MF Global's margin, during a stressful default. For CCPs that are member-owned, the potential that clearing members might need to replenish lost capital can be an additional procyclical liquidity risk that could affect incentives even if a loss is not actually realized. The broader point is that, when facing the possibility of a severe liquidity or solvency threat, CCPs may have the ability and incentive to hoard even more resources than their normal practice suggests. ${ }^{27}$

\footnotetext{
${ }^{27} \mathrm{CCP}$ discretion can go the other way, providing market participants more time to meet payment requirements, or even overriding margin requirements. Such exercises of discretion can result in smaller burdens on clearing members than would otherwise have occurred, but potentially expose the CCP to higher risk during a period of market stress. More generally, CCP discretion means that it may be difficult to predict CCP actions.
} 


\section{Liquidity Stress Tests: Individual and Macroprudential}

One of the main ways that the PFMI raised standards for CCPs was the explicit requirements around managing their liquidity risk. A CCP must be able to make all of its payment obligations on time in all relevant currencies with a high degree of confidence. The PFMI established the expectation that CCPs establish a robust framework to identify, measure, monitor, and manage liquidity risk from participants, settlement and custodian banks, liquidity providers, and any other relevant entities. The PFMI specified that CCPs had to be able to make its payments under the default of the clearing member that would generate the largest aggregate liquidity obligation for the CCP in extreme but plausible market conditions. Furthermore, the PFMI defined what resources should qualify for the purposes of meeting such requirements. The ability of the CCP to meet its potential liquidity demands with its liquid resources must be tested daily through rigorous stress testing similar to how the total financial resources are stress tested daily.

The requirement to stress test liquidity, in addition to being newer, adds new complexities. First, the number of relevant parties goes beyond just the clearing member function and includes those entities who generate a liquidity exposure. Second, multiple roles played by a clearing member, for example if they were also a liquidity provider, need to be considered. Third, the ability to make payments, often in cash, in different currencies must be tested and met. Fourth, the time dimension matters, because it is not enough to have sufficient cash or other liquid resources in aggregate over a close-out period, but rather the CCP needs to be able to make payments on time when due.

The PFMI significantly enhanced expectations for liquidity risk management at CCPs and advanced the stress testing of each CCP's particular liquidity needs. By their nature, however, these micro-level stress tests cannot measure liquidity demands that may arise across the financial system in a market-stress event. While particular payment obligations are isolated within individual CCPs, the resources available to make such payments extend beyond the CCP's boundaries. The resulting interdependencies are difficult if not impossible for an individual $\mathrm{CCP}$ to disentangle, evaluate, and stress test.

The simplest relationship illustrating dependencies across CCPs is the committed lines of credit extended to CCPs by liquidity providers. As noted above, a few of the largest clearing members provide such lines of credit, often to multiple CCPs. As shown in FSB (Figure 11 
2018a, on page 21), apart from a few outliers, there is a positive correlation between the amount of pre-funded resources a clearing member provides in aggregate and the amount of aggregate resources it provides as a liquidity backstop. The implication is that larger CCP members also provide significant liquid resources to the same CCPs. Individual CCPs do not necessarily have a view to the obligations its clearing members have to other CCPs. The default of a large clearing member likely would entail a simultaneous default across multiple CCPs, and therefore multiple CCPs activating liquidity relationships. Stress testing at individual CCPs cannot capture this interdependency.

A coordinated, macro-oriented supervisory stress test across multiple CCPs can complement the micro-oriented stress tests conducted by individual CCPs. The goal would be to evaluate the collective impact the participating CCPs have on the broader financial system during such a default. This objective stands in contrast to the CCPs' own stress tests, which look at their individual resiliency.

Such a test would be designed in a manner consistent with the international framework for supervisory stress testing published by CPMI-IOSCO in $2017 \cdot{ }^{28}$ Such tests would greatly enhance market participants' and regulators understanding of how liquidity risks could arise in the CCP network and potentially affect the rest of the financial system, going beyond prior analysis, such as Heath et al. (2016). Supervisory stress testing for banks is a firmly established regulatory tool post the 2008 crisis, is and generally viewed to be effective. ${ }^{29}$ Testing the resiliency of the clearing system likely would similarly improve our understanding of the feedback loops discussed in Faruqui et al. (2018). It would expand on the recent supervisory stress tests conducted by the CFTC on CCPs it regulates (CFTC, 2016, 2017), particularly by including in the analysis securities CCPs, which, as noted above, require large amounts of liquidity to effect settlement.

\footnotetext{
${ }^{28}$ See CPMI-IOSCO (2017). Anderson et al. (2020) discuss such macroprudential CCP stress tests further, including discussing their rationale and objectives; see also (Tompaidis, 2012).

${ }^{29}$ See Drehmann (2008), Petrella and Resti (2013), Borio et al. (2014), Schuermann (2014), Fernandes et al. (2017), and Flannery et al. (2017). Although the generation of such tests could create incentives for CCPs to adjust their risk and liquidity management, their macroprudential nature and the fact that CCPs do not trade into their own positions likely eliminates the 'window-dressing' effect observed by Cornett et al. (2018) in bank stress testing by supervisors.
} 


\section{Conclusion}

By taking both sides of derivatives and securities trades, CCPs absorb counterparty credit risk. In so doing, they generally improve financial stability through multilateral netting, risk mutualization, and margining. Following the success of CCPs in managing risk and preventing contagion during the financial crisis, regulatory reforms have moved even more activity to central clearing, in particular through clearing mandates for the most common OTC derivatives.

Despite their roles in promoting financial stability, large CCPs are by nature concentrated and interconnected and could therefore pose risks of their own. While attention has generally focused on the potentially disastrous consequences of a failure or severe disruption of a CCP, we have highlighted a difficulty that may occur in a much less remote state of the world. Namely, to protect themselves, CCPs necessarily require liquidity from large banks and other market participants. From the perspective of clearing members, the counterparty risk that is mitigated with central clearing is, in a sense, replaced with liquidity risk. The demand for resources can take the form of VM and IM calls, default fund assessments, draws on liquidity lines, the transfer of positions associated with defaulting members, and other obligations. Moreover, because resources are most likely to be called for by a CCP at times when bank liquidity positions are already under stress, they are inherently procyclical with respect to market conditions.

As more activity becomes concentrated in CCPs, the possibility that CCP liquidity demands could strain banks and other market participants looms larger. On the policy front, as we have discussed, liquidity-focused macroprudential stress tests could help to assess the impact of shocks to CCPs on systemwide liquidity. From a research perspective, more work is needed to understand how the liquidity risks posed by CCPs fit into the broader context of demand for safe and liquid assets. The answer to that question has implications for the measurement of system-wide liquidity, for the modeling of funding markets, and for our understanding of the propagation of financial crises. 
FIGURE 1. Interest rate swaps outstanding

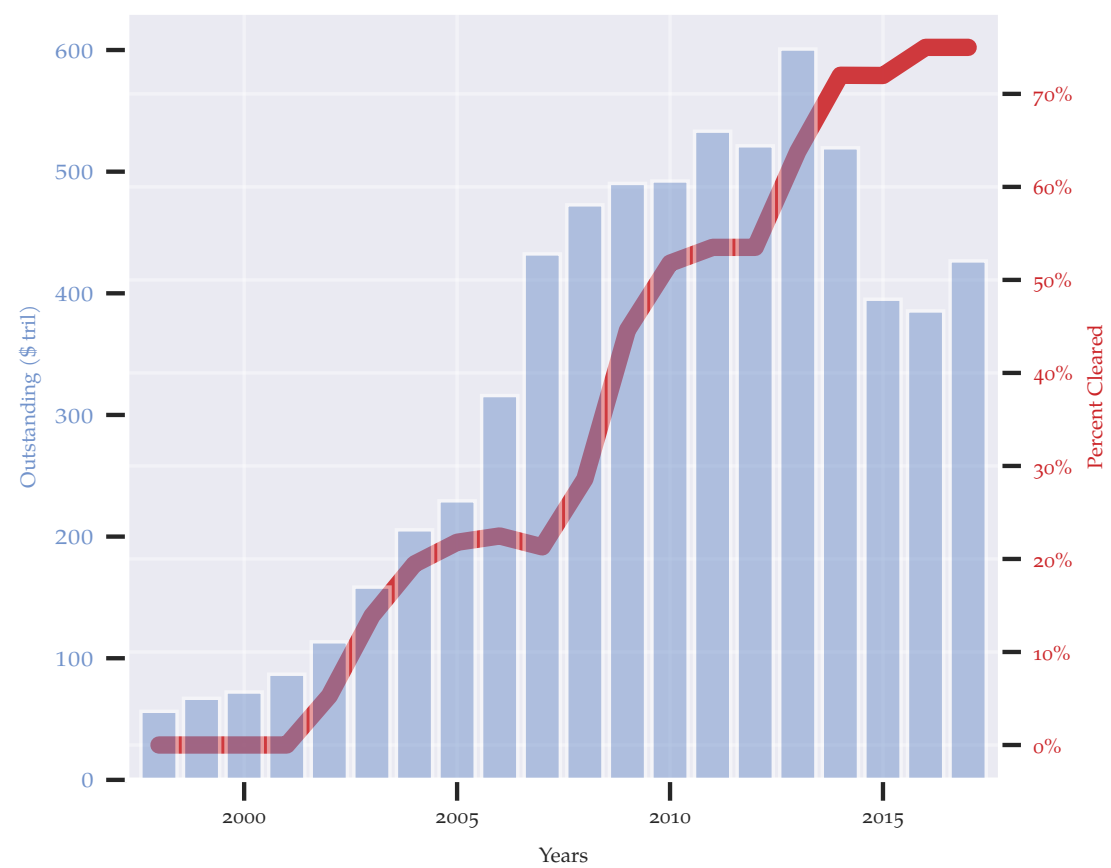

The blue bars, associated with the left-hand scale, represent IRS notional outstanding; The red line, associated with the right-hand scale, shows the percentage centrally cleared.

Source: BIS

FIGURE 2. Six major CCPs clearing US markets

\begin{tabular}{|c|c|c|c|}
\hline $\mathrm{CCP}$ & Main Products & $\begin{array}{l}\text { Approx. } \\
\text { prefunded } \\
\text { resources } \\
(\$ \text { bil. })\end{array}$ & $\begin{array}{l}\text { Max. daily } \\
\text { margin call } \\
\text { since } 2015 \\
\text { (\$ bil. est.) }\end{array}$ \\
\hline \multicolumn{4}{|c|}{ Securities } \\
\hline FICC & & 22 & 10 \\
\hline GSD & US Treasuries and repos & & \\
\hline MBSD & Mortgage- backed securities & & \\
\hline NSCC & US equities, corps. \& munis & 7 & 5 \\
\hline \multicolumn{4}{|c|}{ Derivatives } \\
\hline OCC & US equity options \& futures & 63 & 17 \\
\hline CME & & 130.5 & 14 \\
\hline Base & Commodity and financial futures \& options & & \\
\hline IRS & Interest rate swaps and swaptions & & \\
\hline ICC & Credit default swaps & 38 & 1.2 \\
\hline LCH SwapClear & Interest rate swaps & 179.9 & 16 \\
\hline
\end{tabular}

Source: Quant. disclosures via Clarus CCPView. Date as of Q2-2018 
FIGURE 3. Variation and Initial Margin

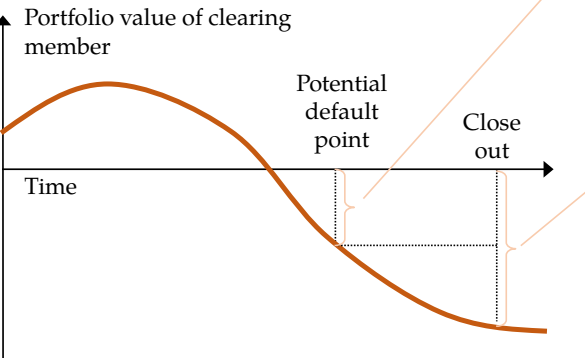

Variation margin is owed daily

- Equal to daily shortfall in value

- Failure to pay is a default

- Prevents current exposures from accumulating

Initial margin is collected to protect CCP from defaulted positions losing value before they are closed

- Equal to estimated potential loss during close-out at 99 th percentile of assumed period( e.g. 99 th percentile of a 5-day loss)

FIGURE 4. IM for IRS, Futures, and CDS

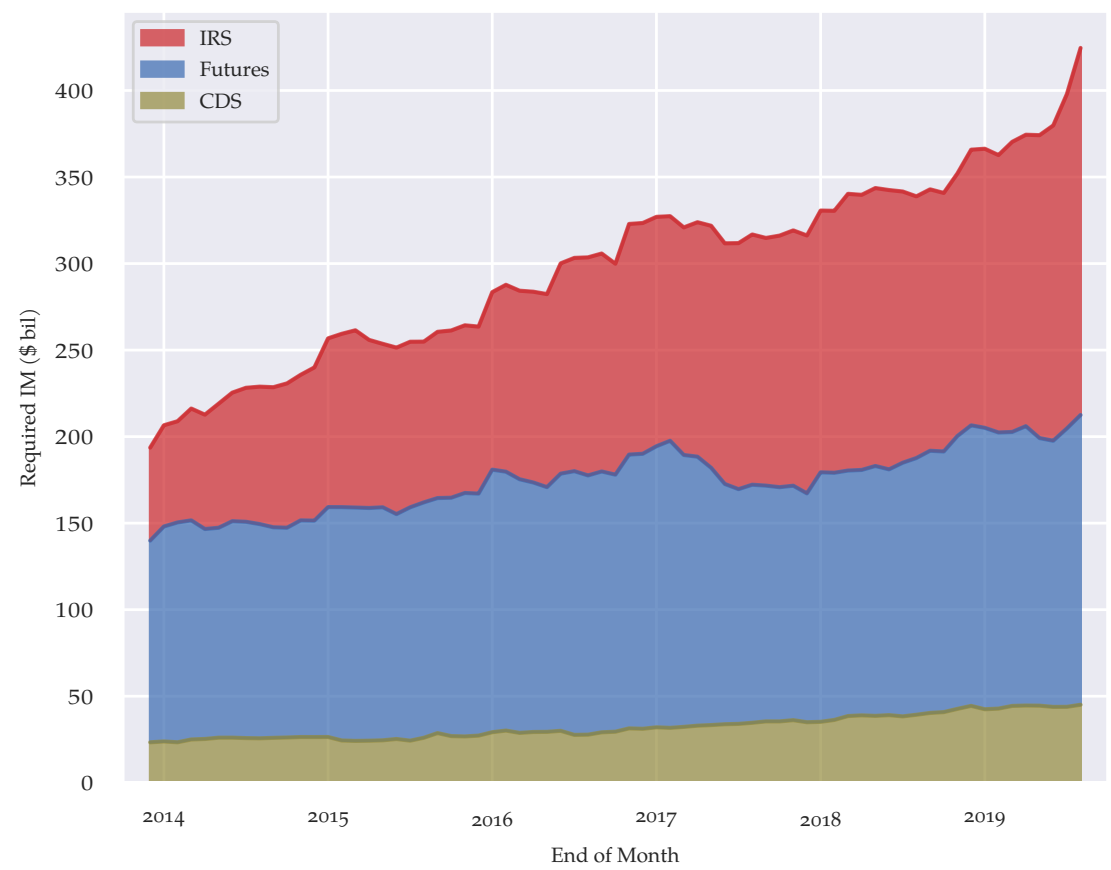

Total requirements held by clearinghouses from clearing members, including add-ons. IRS data include CME \& LCH Ltd. Futures data include CME, ICEU, \& ICE US. CDS data include CME, ICC, ICEU, \& LCH SA. All data are month-end.

Source: CFTC 
FIGURE 5. Percentage of client IM requirements at five largest parent firms

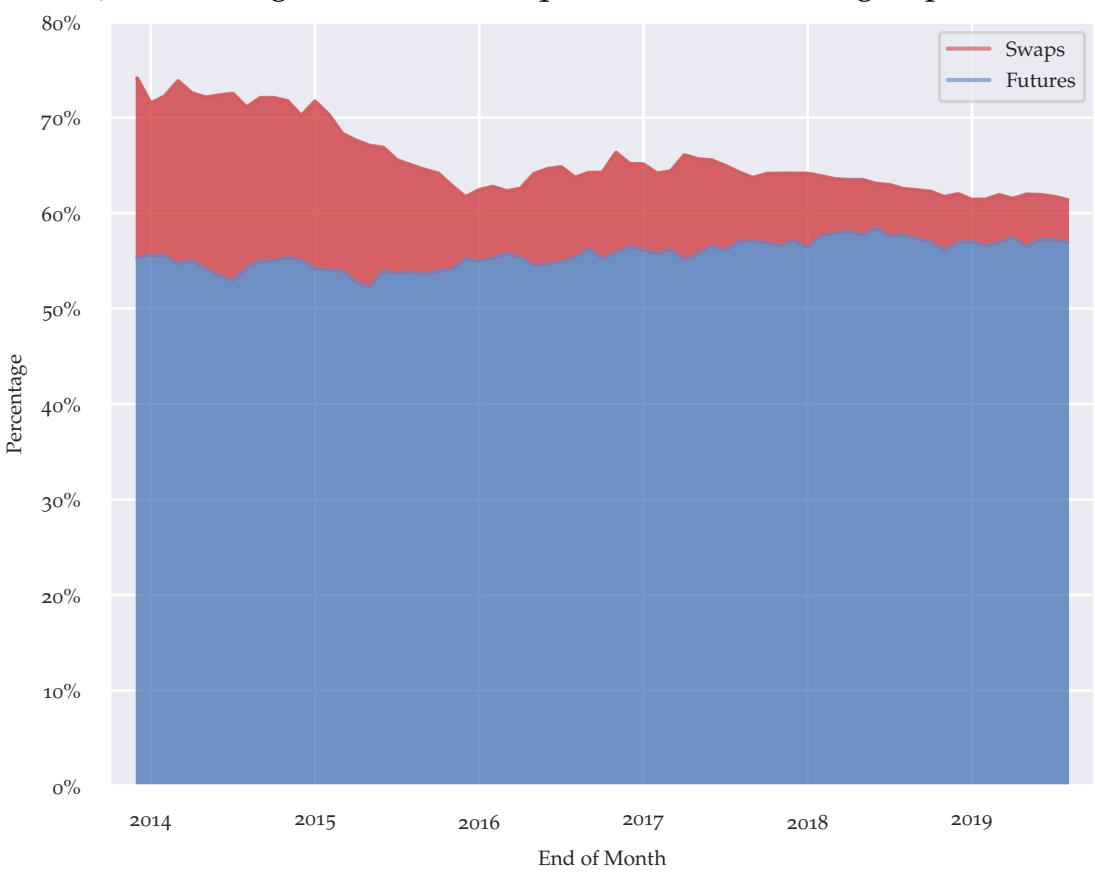

Futures data include CME, ICEU, \& ICE US. Swaps data includes both IRS and CDS requirements. IRS data include CME \& LCH Ltd. CDS data include CME, ICC, ICEU, \& LCH SA. All data are month-end. Identity of top 5 firms can vary from month-to-month.

Source: CFTC

FIGURE 6. Daily peak VM paid versus realized volatility

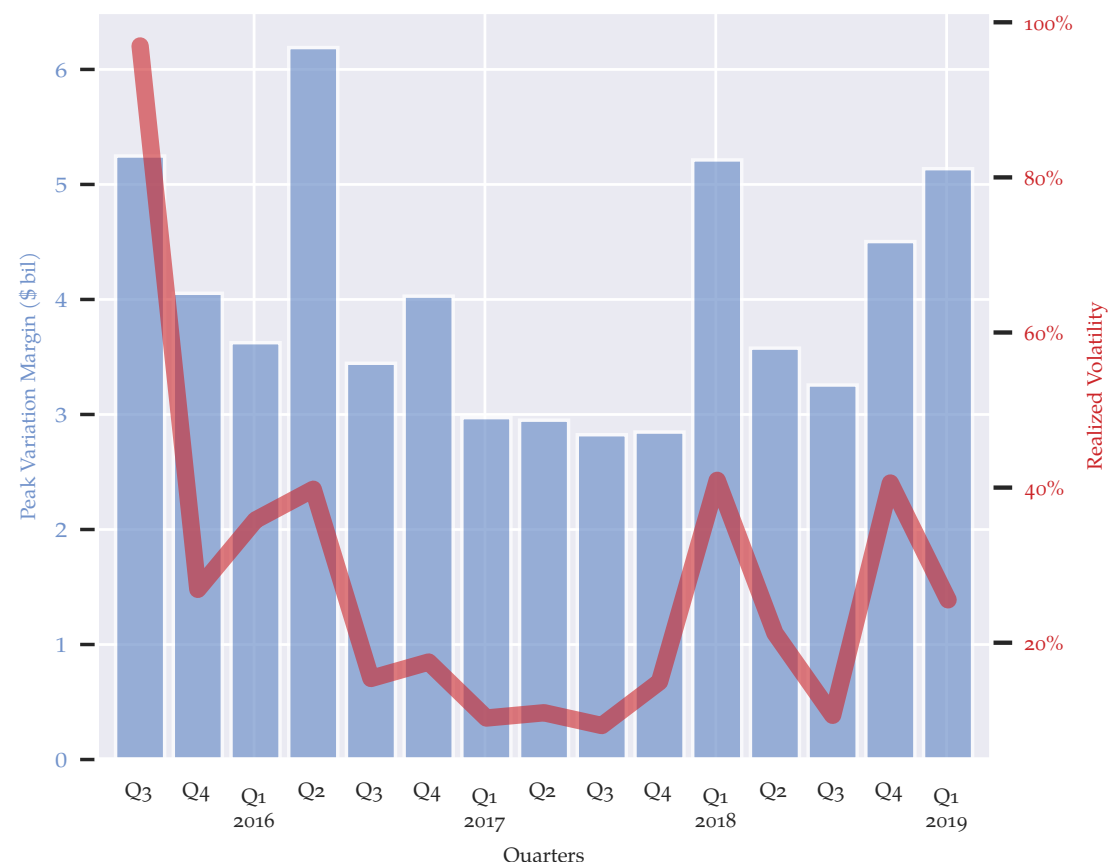

Peak VM, represented by the blue bars associated with the left-hand scale, is the industry average of the maximum paid by/to each CCP in the quarter. Realized volatility is annualized.

Source: Quant. disclosures accessed via Clarus CCPView, and Heber et al. (2009). Date as of Q2-2018. 
FIGURE 7. VM at LCH Swapclear

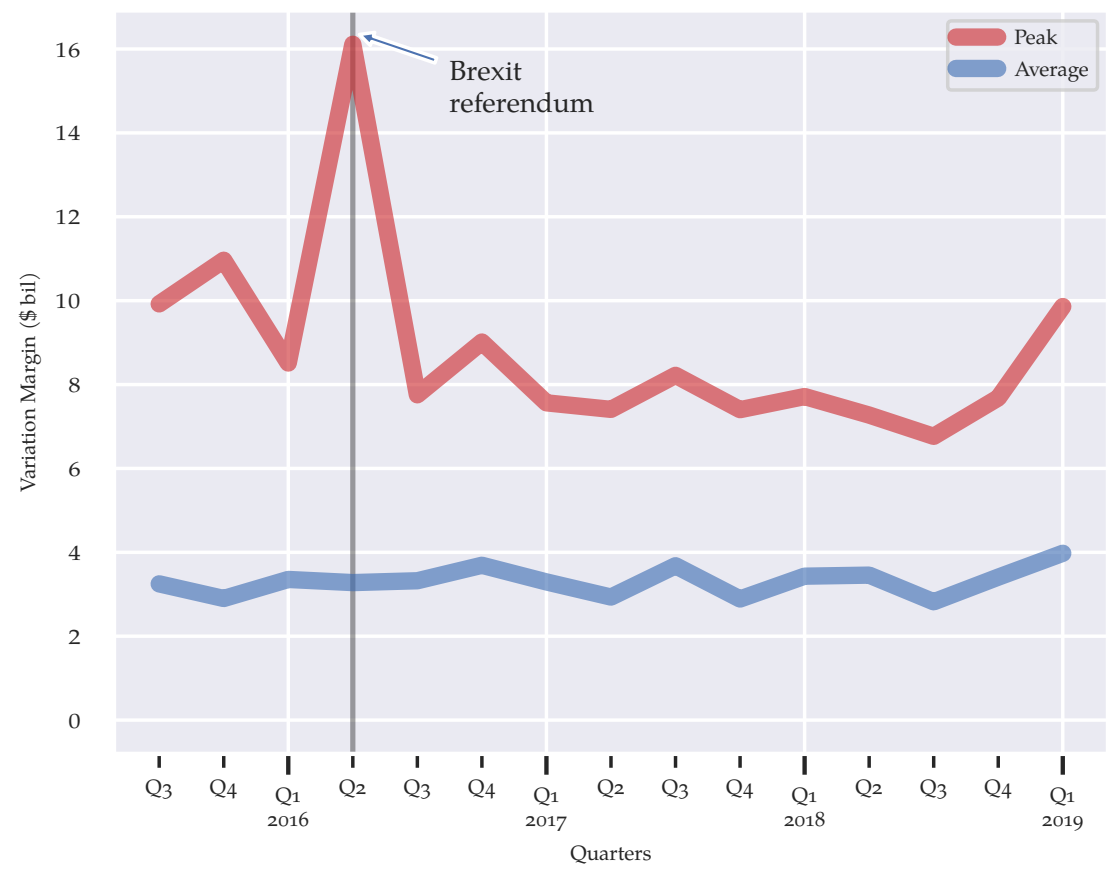

Peak VM, the higher red line, is the maximum paid by/to LCH Swapclear in the quarter. The blue line shows the corresponding quarterly average. Source: Quant. disclosures accessed via Clarus CCPView. Date as of Q2-2018.

Figure 8. CME Futures IM requirements and VIX index

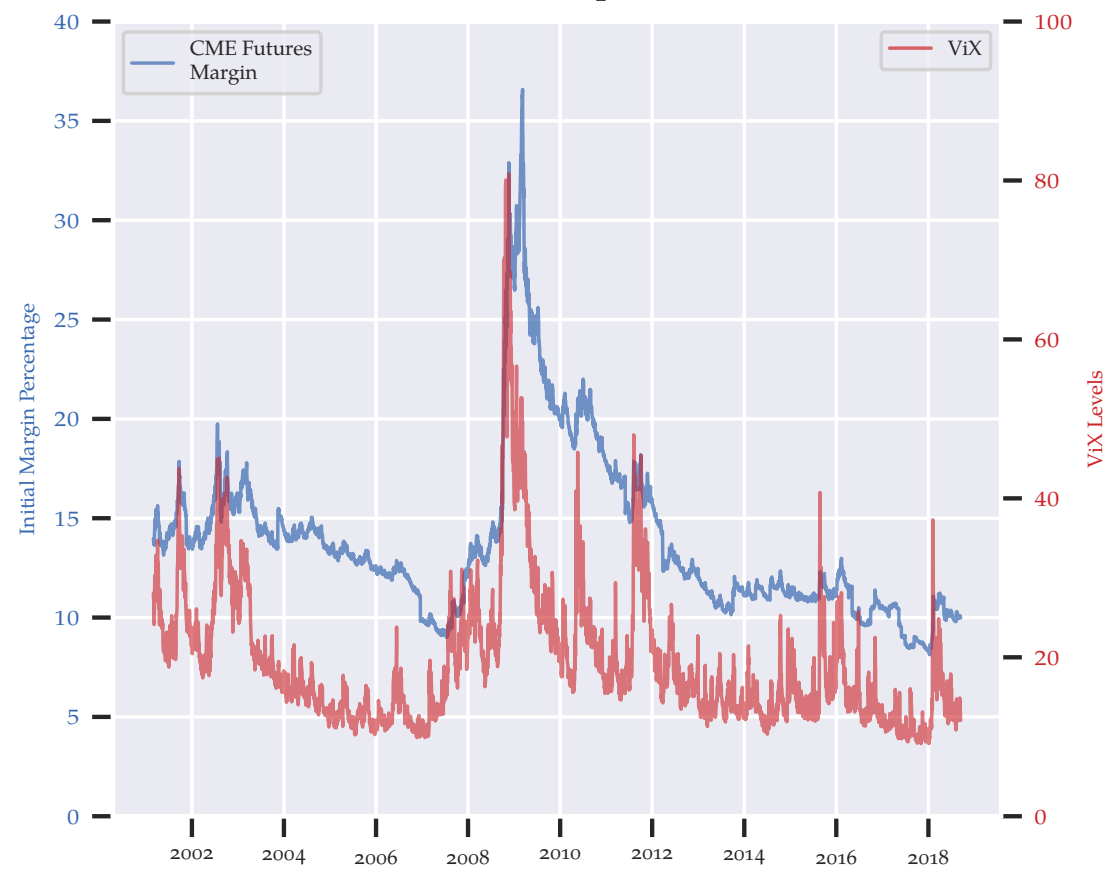

The blue line, associated with the left-hand scale, shows CME's IM requirements on an S\&P 500 futures contract as a percentage of the contract value. The red line, associated with the right hand scale, is the Chicago Board Options Exchange's Volatility Index (VIX), reflects market expectations of 30-day forward-looking implied volatility. It is calculated from S\&P 500 index options.

Source: Daily data from Chicago Board Options Exchange, CME, and Haver Analytics. 
FIgURE 9. CME Futures IM requirement versus VIX index

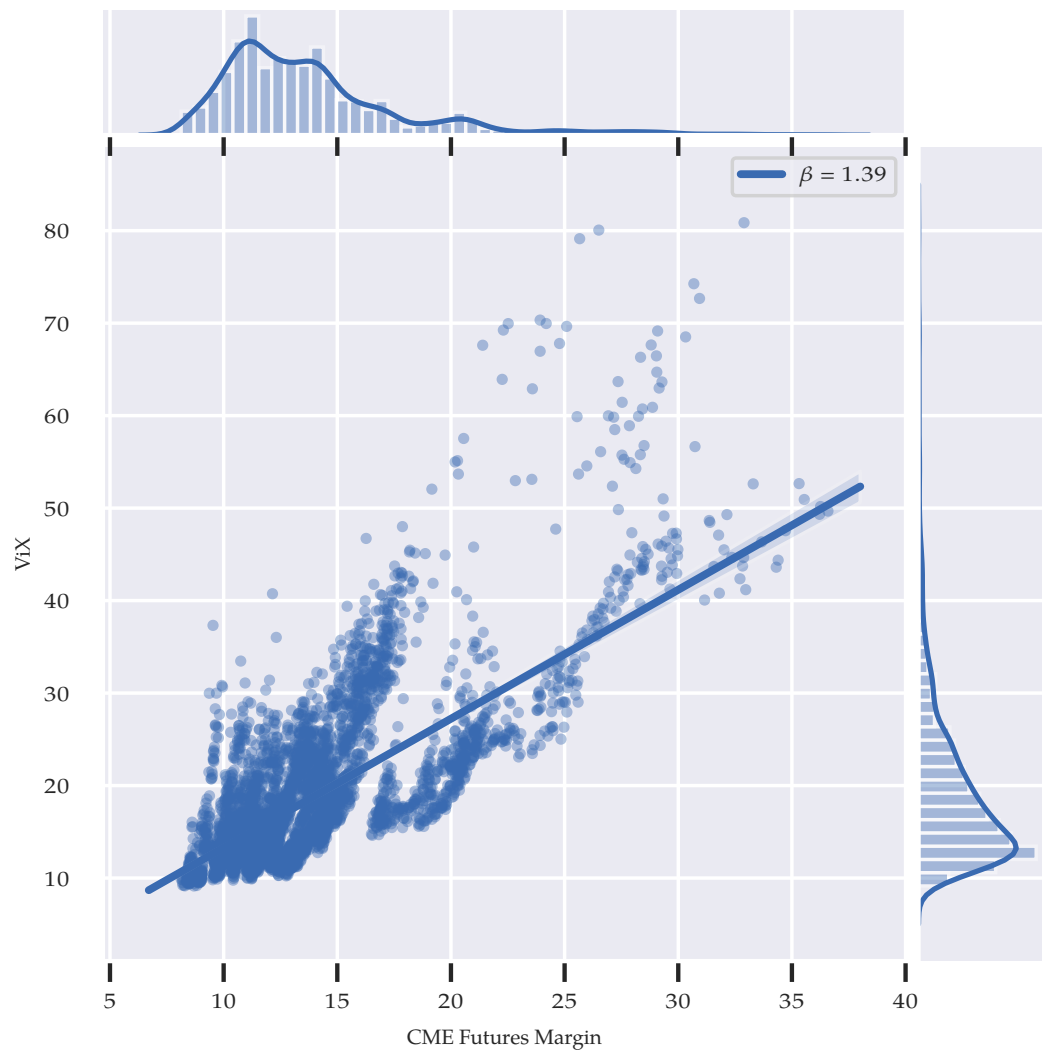

The joint plot shows CME's IM requirements on an S\&P 500 futures contract as a percentage of the contract value versus VIX; the strong positive relationship is reflected in the upward sloping regression line; this regression, which is highly-significant as shown by the barely visible 99th percent bootstrapped confidence interval, is estimated robustly to reduce the influence of outliers that would increase the slope further. The marginal distributions, plotted above and to the right as both histograms and kernel estimates, show that both series have a long positive tail, although presumably margin as a percent is capped.

Source: Daily data from Chicago Board Options Exchange, CME and Haver Analytics. 
FIGURE 10. OCC quarterly peak IM calls

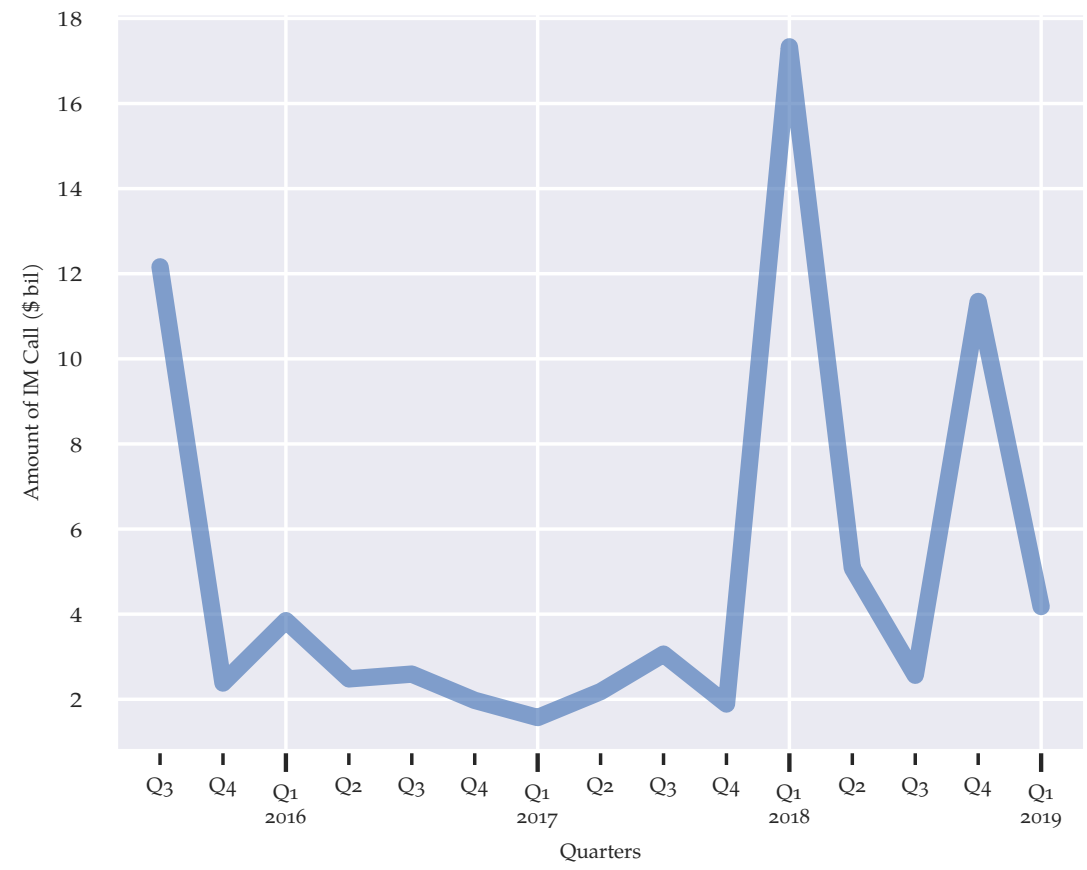

Quant. disclosures accessed via Clarus CCPView. Date as of Q2-2018.

FIGURE 11. Quarterly changes in required IM and VIX

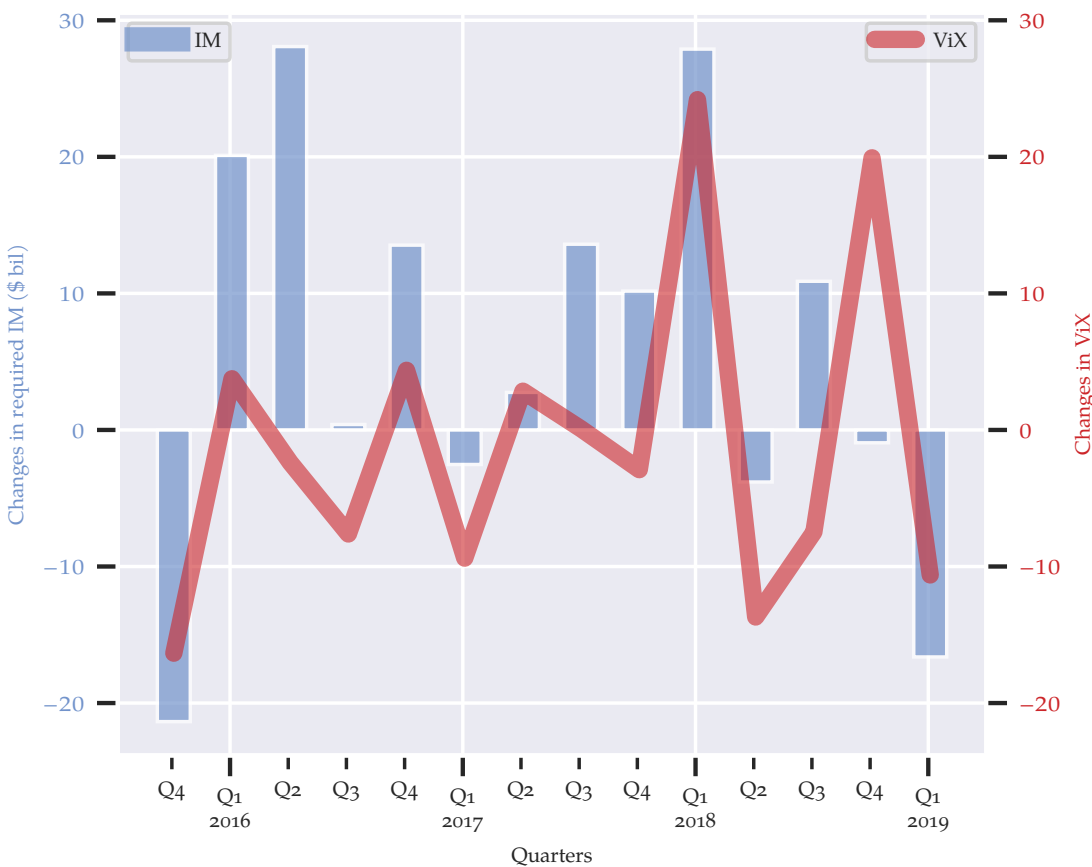

The blue bars, associated with the left-hand scale, represent quarterly changes in total IM required at the six major US CCPs; The red line, associated with the right-hand scale, shows the quarterly maximum change in VIX.

Source: Quant. disclosures accessed via Clarus CCPView, and Chicago Board Options Exchange. Date as of Q2-2018. 
Figure 12. Change in average Default Fund assessments

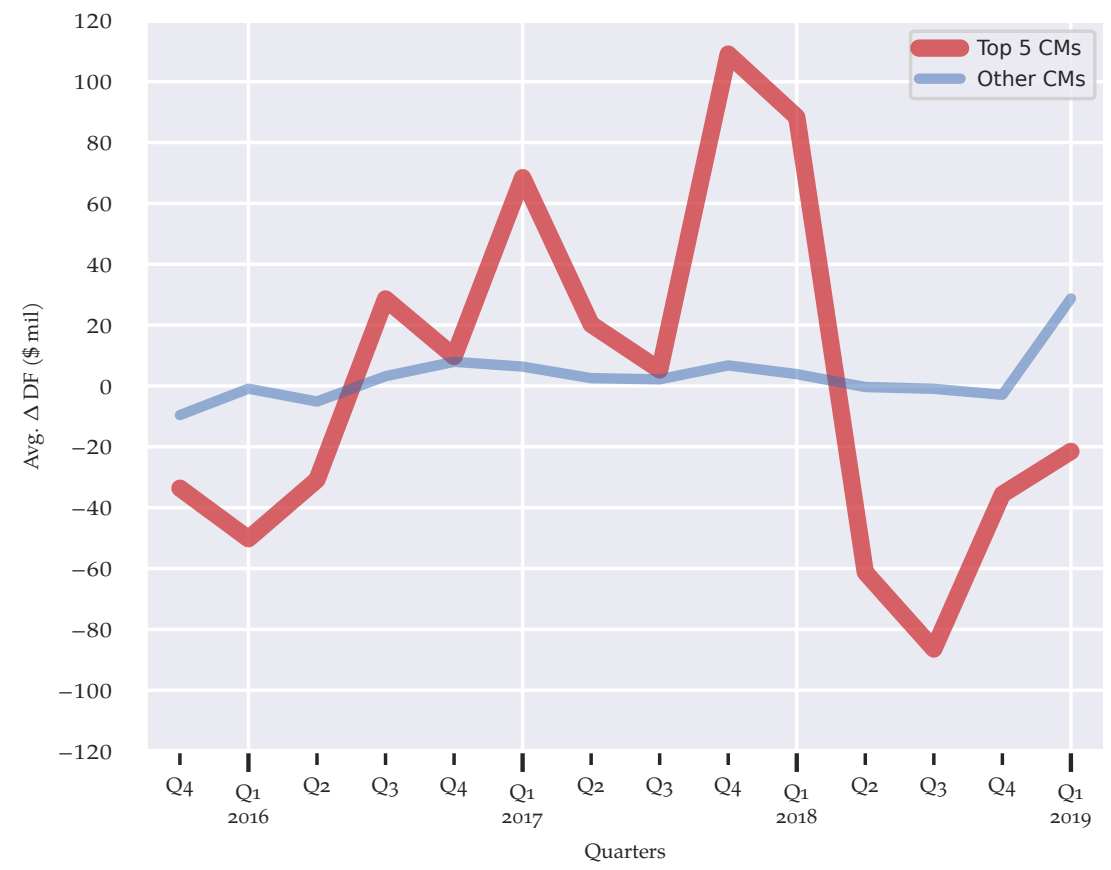

The blue line, associated with the left-hand scale, represents average change at the six CCPs in the default fund assessments of each CCP's five largest clearing members. The red line, associated with the right-hand scale, shows the same average change for the remaining CMs across the CCPs.

Source: Quant. disclosures accessed via Clarus CCPView. Date as of Q2-2018.

FIGURE 13. Unfunded CM commitments as a percent of total default resources excl. IM

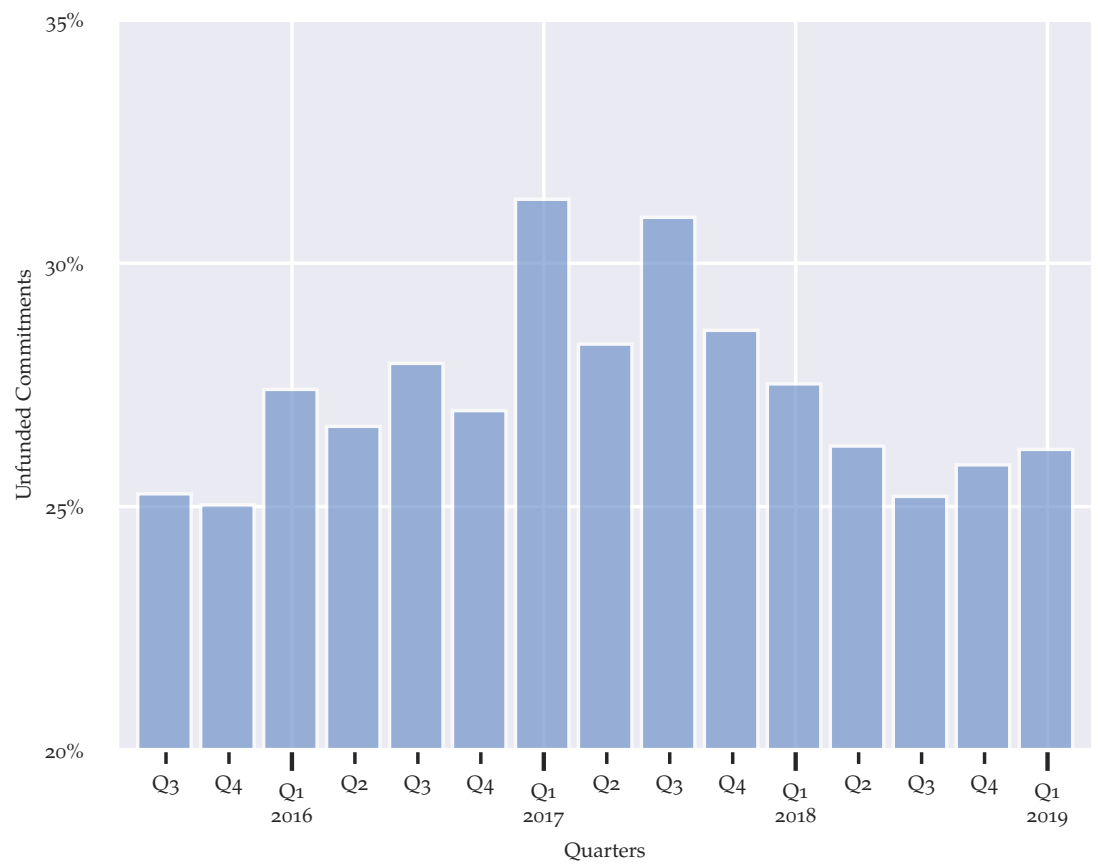

Quant. disclosures accessed via Clarus CCPView. Date as of Q2-2018. 
FIGURE 14. Largest total client position of CM as a percentage of other CM's excess capital

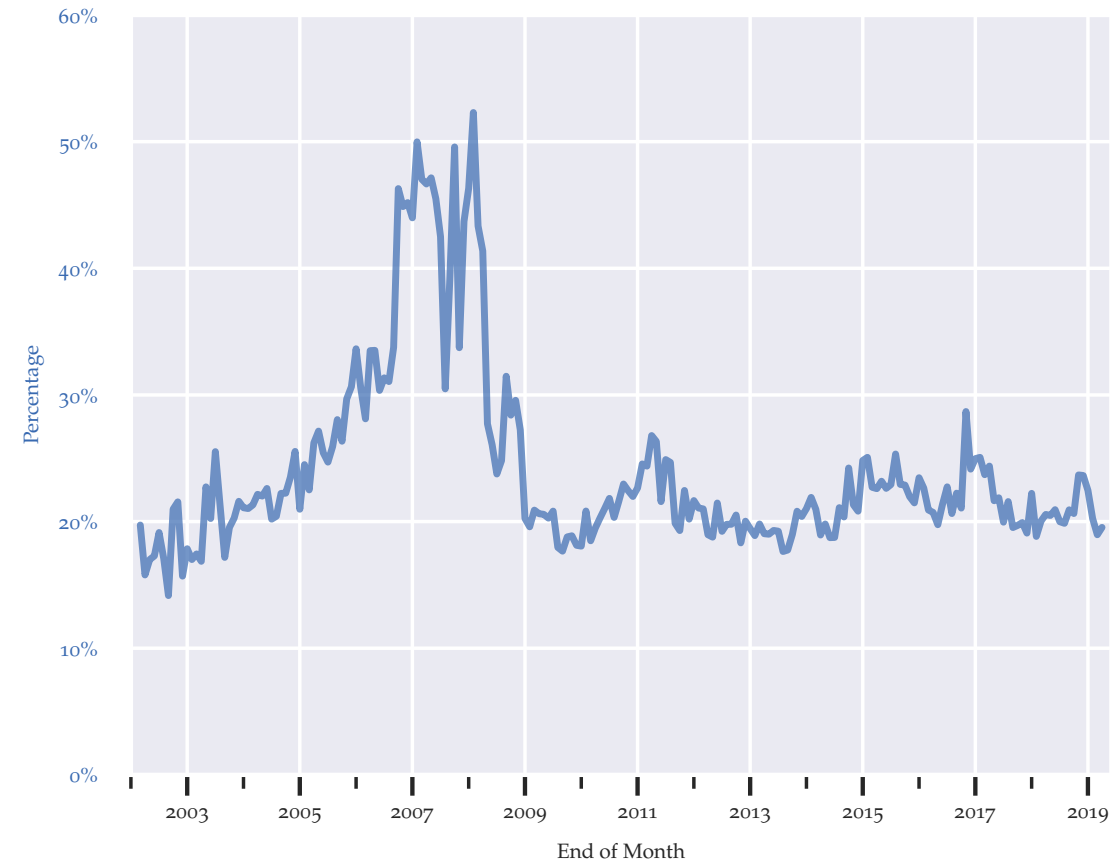

Source: CFTC.

Figure 15. Committed lines of credit as a percent of large bank liquid assets

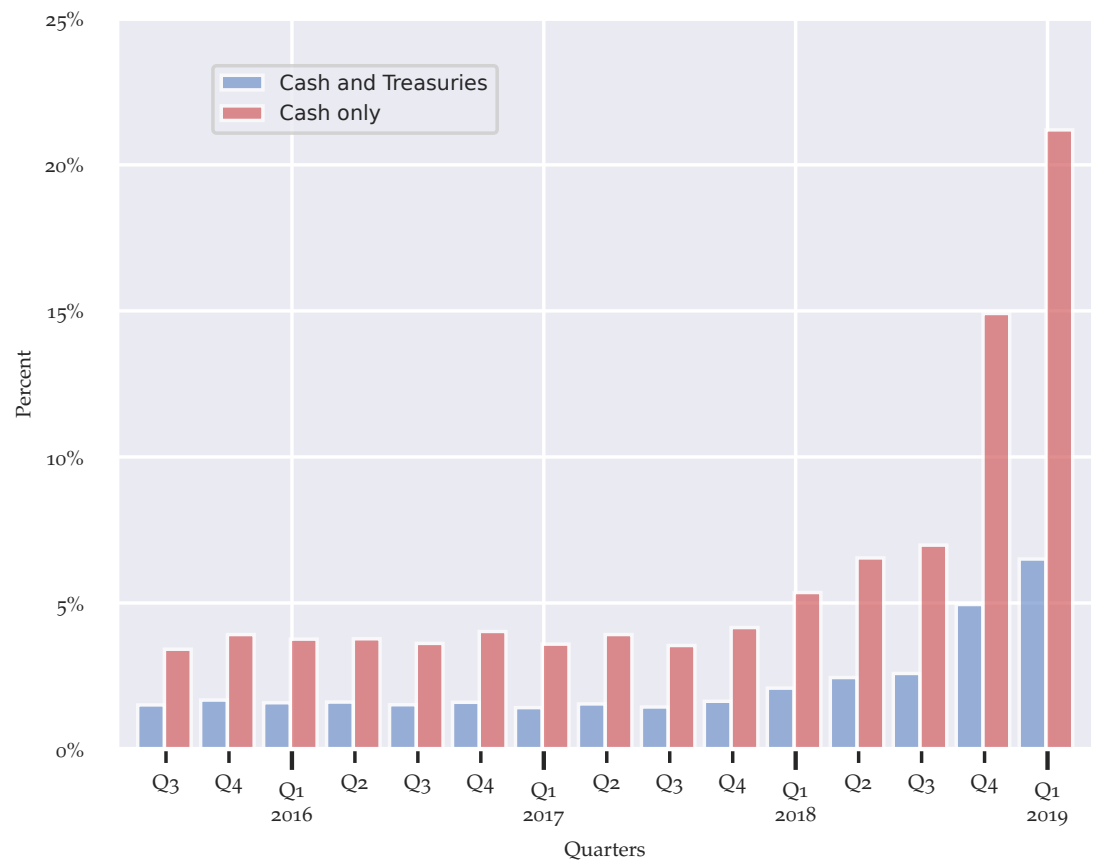

Large banks are domestic banks with more than \$250 billion in assets. Liquid assets includes cash and other highly liquid assets.

Quant. disclosures accessed via Clarus CCPView, and Federal Reserve H.8 release. Date as of Q2-2018. 


\section{REFERENCES}

Acharya, Viral V., and Ouarda Merrouche. 2012, "Precautionary Hoarding of Liquidity and Interbank Markets: Evidence from the Subprime Crisis." Rev. Finan., 17(1): 107-160. doi:10.1093/rof/rfso22.

Acharya, Viral V., Hyun Song Shin, and Tanju Yorulmazer. 2010, "Crisis Resolution and Bank Liquidity." Rev. Finan. Stud., 24(6): 2166-2205. doi:10.1093/rfs/hhq073.

Adrian, Tobias, and Hyun Song Shin. 2008, "Liquidity, Monetary Policy, and Financial Cycles." Curr. Issues Econ. Financ., 14(1): 1-7, URL https : //www . newyorkfed.org/research/ current_issues/ci14-1.html.

Adrian, Tobias, and Hyun Song Shin. 2010, “Liquidity and Leverage." J. Finan. Intermediation, 19(3): 418-437. doi:10.1016/j.jfi.2008.12.002. Risk Transfer Mechanisms and Financial Stability.

Alfranseder, Emanuel, Paweł Fiedor, Sarah Lapschies, Lucia Orszaghova, and Paweł Sobolewski. 2018, "Indicators for the Monitoring of Central Counterparties in the EU." Technical Report 14, European Systemic Risk Board, European System of Financial Supervision, URL https : / /www . esrb . europa. eu/pub/pdf / occasional/esrb . op14. en . pdf. Occasional Paper Series.

Allen, Franklin, Elena Carletti, and Douglas Gale. 2009, "Interbank Market Liquidity and Central Bank Intervention." J. Monet. Econ., 56(5): 639-652. doi:10.1016/j.jmoneco.2009.04.003. Carnegie-Rochester Conference Series on Public Policy: Distress in Credit Markets: Theory, Empirics, and Policy November 14-15, 2008.

Amini, Hamed, Rama Cont, and Andreea Minca. 2016, "Resilience to Contagion in Financial Networks." Math. Finance, 26(2): 329-365. doi:10.1111/mafi.12051.

Anderson, Edward, Fernando Cerezetti, and Mark Manning. 2020, "Supervisory Stress Testing for CCPs: A Macro-prudential, Two-tier Approach." J. Finan. Market Infrastructures, 8(1): 1-25. doi:10.21314/JFMI.2019.115.

Armakolla, Angela, and Jean Paul Laurent. 2017, "CCP Resilience and Clearing Membership." doi:10.2139/ssrn.2625579. Available at SSRN.

Ashcraft, Adam, James Mcandrews, and David Skeie. 2011, "Precautionary Reserves and the Interbank Market." J. Money Credit Bank., 43(s2): 311-348. doi:10.1111/j.1538-4616.2011.00438.x.

Bai, Jennie, Arvind Krishnamurthy, and Charles-Henri Weymuller. 2018, "Measuring Liquidity Mismatch in the Banking Sector." J. Finance, 73(1): 51-93. doi:10.1111/jofi.12591.

Barker, Russell, Andrew Dickinson, Alex Lipton, and Rajeev Virmani. 2017, "Systemic Risks in CCP Networks." Risk, 91-97, URL http: //www.risk.net/cutting-edge/banking/ 2479766/systemic-risks-in-ccp-networks.

BCBS. 2019, Leverage Ratio Treatment of Client Cleared Derivatives. URL https: //www. bis.org/ bcbs/publ/d467.htm.

BCBS-IOSCO. 2015, Margin Requirements for Non-centrally Cleared Derivatives. URL https:// wWw. bis.org/bcbs/publ/d317.pdf.

Berger, Allen N., and Christa H. S. Bouwman. 2009, "Bank Liquidity Creation." Rev. Finan. Stud., 22(9): 3779-3837. doi:10.1093/rfs/hhn104.

Berger, Allen N., and Christa H.S. Bouwman. 2017, "Bank Liquidity Creation, Monetary Policy, and Financial Crises." J. Finan. Stab., 30: 139-155. doi:10.1016/j.jfs.2017.05.001.

Bernanke, Ben S. 1990, "Clearing and Settlement during the Crash." Rev. Finan. Stud., 3(1): 133-151, URL http: //www. jstor .org/stable/2961962.

Berrospide, Jose. 2013, "Bank Liquidity Hoarding and the Financial Crisis: An Empirical Evaluation." Technical Report 3, Federal Reserve Board, URL https:// www.federalreserve.gov/pubs/feds/2013/201303/201303abs.html. Finance and Economics Discussion Series. 
Bignon, Vincent, and Guillaume Vuillemey. 2018, "The Failure of a Clearinghouse: Empirical Evidence." Rev. Finance, 1-30. doi:10.1093/rof/rfy039. Forthcoming.

Borio, Claudio, Mathias Drehmann, and Kostas Tsatsaronis. 2014, "Stress-testing Macro Stress Testing: Does It Live up to Expectations?" J. Finan. Stab., 12: 3-15. doi:10.1016/j.jfs.2013.06.001. Reforming finance.

Brunnermeier, Markus K. 2009, “Deciphering the Liquidity and Credit Crunch 2007-2008." J. Econ. Perspect., 23(1): 77-100. doi:10.1257/jep.23.1.77.

CFTC. 2016, Supervisory Stress Test of Clearinghouses. URL https://www.cftc.gov/ sites/default/files/idc/groups/public/@newsroom/documents/file/ dcr_ecl1017.pdf.

CFTC. 2017, Evaluation of Clearinghouse Liquidity. URL https://www.cftc.gov/ sites/default/files/idc/groups/public/@newsroom/documents/file/ dcr_ecl1017.pdf.

Chicago Board Options Exchange, "CBOE Volatility Index: VIX [VIXCLS]." retrieved from FRED, Federal Reserve Bank of St. Louis, URL https : / fred. stlouisfed.org/series / VIXCLS.

Clarus CCPView. Clarus Financial Technology Ltd., URL https:// ccpview.clarusft.com.

Cont, Rama. 2017, "Central Clearing and Risk Transformation." Working Paper 3, Norges Bank, URL https://www.norges-bank.no/en/news-events/news-publications/ Papers/Working-Papers/2017/32017/. Norges Bank Research.

Cornett, Marcia Millon, Jamie John McNutt, Philip E. Strahan, and Hassan Tehranian. 2011, "Liquidity Risk Management and Credit Supply in the Financial Crisis." J. Finan. Econ., 101(2): 297-312. doi:10.1016/j.jfineco.2011.03.001.

Cornett, Marcia Millon, Kristina Minnick, Patrick J. Schorno, and Hassan Tehranian. 2018, "An Examination of Bank Behavior around Federal Reserve Stress Tests." J. Finan. Intermediation. doi:10.1016/j.jfi.2018.05.001. In press.

Cox, Robert T., and Robert S. Steigerwald. 2018, "A CCP is a CCP is a CCP." J. Finan. Market Infrastructures, 6(4): 1-18. doi:10.21314/JFMI.2018.085.

CPMI-IOSCO. 2012, Principles for Financial Market Infrastructures. URL http://www.bis . org/ cpmi/publ/d101.htm.

CPMI-IOSCO. 2014, Recovery of Financial Market Infrastructures. URL https://www. bis.org/ cpmi/publ/d121.htm.

CPMI-IOSCO. 2015, Public Quantitative Disclosure Standards for Central Counterparties (CCPs). URL https://www.bis.org/cpmi/publ/d125.htm.

CPMI-IOSCO. 2016, Resilience and Recovery of Central Counterparties (CCPs): Further Guidance on the PFMI. URL http://www.bis.org/cpmi/publ/d101.htm.

CPMI-IOSCO. 2017, Framework for Supervisory Stress Testing of Central Counterparties (CCPs). URL http://www.bis.org/cpmi/publ/d161.htm.

Culp, Christopher L. 2010, "OTC-Cleared Derivatives: Benefits, Costs, and Implications of the 'Dodd-Frank Wall Street Reform and Consumer Protection Act'." J. Appl. Finance, 20(2): 1-27, URL https: //ssrn . com/abstract=2693059.

Drehmann, Mathias. 2008, "Stress Tests: Objectives, Challenges And Modelling Choices." Riksbank Econ. Rev., (2): 60-92, URL http://archive.riksbank. se/Upload/ Dokument_riksbank/Kat_publicerat/PoV_sve/eng/2008/er2008_2_ny.pdf.

Duffie, Darrell. 2014, "Financial Market Infrastructure: Too Important to Fail." In Across the Great Divide: New Perspectives on the Financial Crisis, eds. John B. Taylor and Martin Neil Baily, 251-257, Hoover Institution Press, URL https://www.hoover.org/sites/default/ files/across-the-great-divide-ch11.pdf. 
Duffie, Darrell, and Haoxiang Zhu. 2011, "Does a Central Clearing Counterparty Reduce Counterparty Risk?" Rev. Asset Pric. Stud., 1(1): 74-95. doi:10.1093/rapstu/raro01.

ESMA. 2018a, EU-wide CCP Stress Test 2017. URL http://firds. esma.europa.eu/webst/ ESMA70-151-1154\%20EU-wide\%20CCP\%20Stress $\% 20$ Test $\% 202017 \% 20$ Report.pdf.

ESMA. 2018b, Guidelines on EMIR Anti-Procyclicality Margin Measures for Central Counterparties. URL https://www. esma. europa.eu/sites/default/files/library/esma70-1511293_final_report_on_guidelines_on_ccp_apc_margin_measures.pdf.

Faruqui, Umar, Wenqian Huang, and Előd Takáts. 2018, "Clearing Risks in OTC and Derivatives Markets: The CCP-Bank Nexus." BIS Quart. Rev., 73-90, URL https : / www . bis . org/ publ/qtrpdf/r_qt1812h.htm.

Fernandes, Marcelo, Deniz Igan, and Marcelo Pinheiro. 2017, "March Madness in Wall Street: (What) Does the Market Learn from Stress Tests?" J. Bank. Financ. doi:10.1016/j.jbankfin.2017.11.005. In press.

Flannery, Mark, Beverly Hirtle, and Anna Kovner. 2017, "Evaluating the Information in the Federal Reserve Stress Tests." J. Finan. Intermediation, 29: 1-18. doi:10.1016/j.jfi.2016.08.001.

Fleming, Michael J., and Asani Sarkar. 2014, "The Failure Resolution of Lehman Brothers." Fed. Reserve Bank New York Econ. Pol. Rev., 20(2): 175-206, URL https : / www . newyorkfed.org/ research/epr/2014/1412flem.html.

FSB. 2017a, Analysis of Central Clearing Interdependencies. URL http://www.fsb.org/wpcontent/uploads/P050717-2.pdf.

FSB. 2017b, Review of OTC Derivatives Market Reforms: Effectiveness and Broader Effects of the Reforms. URL http://www.fsb.org/wp-content/uploads/P290617-1.pdf.

FSB. 2018a, Analysis of Central Clearing Interdependencies. URL http://www.fsb.org/wpcontent/uploads/P090818.pdf.

FSB. 2018b, Incentives to Centrally Clear Over-the-Counter (OTC) Derivatives: A Post-Implementation Evaluation of the Effects of the G2o Financial Regulatory Reforms. URL http: //www . f sb . org/2018/11/ incentives-to-centrally-clear-over-the-counter-otc-derivatives-2/.

Gibson, Rajna, and Carsten Murawski. 2013, "Margining in Derivatives Markets and the Stability of the Banking Sector." J. Bank. Financ., 37(4): 1119-1132. doi:10.1016/j.jbankfin.2012.10.005.

Glasserman, Paul, and Qi Wu. 2018, "Persistence and Procyclicality in Margin Requirements." Manage. Sci., 64(12): 5705-5724. doi:10.1287/mnsc.2017.2915.

Greenwood, Robin, Augustin Landier, and David Thesmar. 2015, "Vulnerable Banks." J. Finan. Econ., 115(3): 471-485. doi:10.1016/j.jfineco.2014.11.006.

Haver Analytics. Haver Analytics, URL http://www .haver.com/our_data.html.

Heath, Alexandra, Gerard Kelly, Mark Manning, Sheri Markose, and Ali Rais Shaghaghi. 2016, "CCPs and Network Stability in OTC Derivatives Markets." J. Finan. Stab., 27: 217-233. doi:10.1016/j.jfs.2015.12.004.

Heber, Gerd, Asger Lunde, Neil Shephard, and Kevin K. Sheppard, "Oxford-Man Institute's realized library." University of Oxford, URL https://realized.oxfordman.ox.ac.uk/. Version no. o.3.

Heckinger, Richard. 2014, "MF Global: A Case Study of Liquidity Risks." J. Finan. Market Infrastructures, 3(2): 79-96. doi:10.21314/JFMI.2014.037.

Heckinger, Richard, Robert T. Cox, and David Marshall. 2017, "Cleared Margin Setting at Selected Central Counterparties." J. Finan. Market Infrastructures, 5(4): 1-21. doi:10.21314/JFMI.2017.075.

Heider, Florian, Marie Hoerova, and Cornelia Holthausen. 2015, "Liquidity Hoarding and Interbank Market Rates: The Role of Counterparty Risk." J. Finan. Econ., 118(2): 336-354. doi:10.1016/j.jfinec0.2015.07.002. 
Heller, Daniel, and Nicholas Vause. 2012, "Collateral Requirements for Mandatory Central Clearing of Over-the-counter Derivatives." Technical Report 373, BIS Working Papers, URL http://www.bis.org/publ/work373.pdf.

Houllier, Melanie, and David Murphy. 2017, "Initial Margin Model Sensitivity Analysis and Volatility Estimation." J. Finan. Market Infrastructures, 5(4): 77-103. doi:10.21314/JFMI.2017.078.

Huber, Peter J. 1981, Robust Statistics. Wiley Series in Probability and Mathematical Statistics, John Wiley \& Sons, Hoboken, NJ.

Ippolito, Filippo, José-Luis Peydró, Andrea Polo, and Enrico Sette. 2016, "Double Bank Runs and Liquidity Risk Management." J. Finan. Econ., 122(1): 135-154. doi:10.1016/j.jfineco.2015.11.004.

Ivashina, Victoria, and David Scharfstein. 2010, "Bank Lending during the Financial Crisis of 2008." J. Finan. Econ., 97(3): 319-338. doi:10.1016/j.jfineco.2009.12.001. The 2007-8 financial crisis: Lessons from corporate finance.

Iyer, Rajkamal, José-Luis Peydró, Samuel da Rocha-Lopes, and Antoinette Schoar. 2014, "Interbank Liquidity Crunch and the Firm Credit Crunch: Evidence from the 2007-2009 Crisis." Rev. Finan. Stud., 27(1): 347-372. doi:10.1093/rfs/hhto56.

Kashyap, Anil K., Raghuram Rajan, and Jeremy C. Stein. 2002, "Banks As Liquidity Providers: An Explanation for the Coexistence of Lending and Deposit-taking." J. Finance, 57(1): 33-73. doi:10.1111/1540-6261.00415.

Kiff, John, Randall Dodd, Alessandro Gullo, Elias Kazarian, Isaac Lustgarten, Christine Sampic, and Manmohan Singh. 2010, "Making Over-the-Counter Derivatives Safer: The Role of Central Counterparties." In Global Financial Stability Report: Meeting New Challenges to Stability and Building a Safer System, chapter 3, 1-27, International Monetary Fund, URL https: //www.imf.org/external/pubs/ft/gfsr/2010/01/pdf/chap3.pdf.

Kroszner, Randall S. 1999, "Can the Financial Markets Privately Regulate Risk? The Development of Derivatives Clearinghouses and Recent Over-The-Counter Innovations." J. Money Credit Bank., 31(3): 596-618. doi:10.2307/2601077.

Kroszner, Randall S. 2000, "Lessons from Financial Crises: The Role of Clearinghouses." J. Finan. Services Res., 18(2): 157-171. doi:10.1023/A:1026534619637.

LCH.Clearnet, "\$9 Trillion Lehman OTC Interest Rate Swap Default Successfully Resolved." Press Release, URL http://secure-area. lchclearnet.com/media_centre/ press_releases/2008-10-08.asp.

Lewandowska, Olga, and Florian Glaser. 2017, "The Recent Crises and Central Counterparty Risk Practices in the Light of Procyclicality: Empirical Evidence." J. Finan. Market Infrastructures, 5(3): 1-24. doi:10.21314/JFMI.2017.072.

Madigan, Peter, Duncan Wood, and Lukas Becker. 2016, "LCH under scrutiny after outsized Brexit margin calls." Risk, URL https://www.risk.net/risk-management/2474560/ lch-under-scrutiny-after-outsized-brexit-margin-calls.

Manning, Mark Jozsef, and David Hughes. 2016, "Central Counterparties and Banks: Vive La Difference." J. Finan. Market Infrastructures, 4(3): 1-24. doi:10.21314/JFMI.2016.058.

Maruyama, Atsushi, and Fernando Cerezetti. 2019, "Central Counterparty Antiprocyclicality Tools: A Closer Assessment." J Finan Market Infrastructures, 7(4): 1-25. doi:10.21314/JFMI.2018.110.

Murphy, David. 2013, OTC Derivatives: Bilateral Trading and Central Clearing. Global Financial Markets, Palgrave Macmillan. doi:10.1057/9781137293862.

Murphy, David, Michalis Vasios, and Nick Vause. 2014, "An Investigation into the Procyclicality of Risk-Based Initial Margin Models." Technical report, Bank of England, URL https://www. bankofengland.co.uk/-/media/boe/files/financial-stabilitypaper/2014/an-investigation-into-the-procyclicality-of-risk-basedinitial-margin-models.pdf. Financial Stability Paper No. 29. 
O'Neill, Cian, and Nick Vause. 2016, "Macroprudential Margins: A New Countercyclical Tool?" Technical report, Bank of England, URL https ://www . bankofengland.co . uk/ working-paper/2018/macroprudential-margins-a-new-countercyclical-tool. Working Paper No. 765.

Petrella, Giovanni, and Andrea Resti. 2013, "Supervisors As Information Producers: Do Stress Tests Reduce Bank Opaqueness?" J. Bank. Financ., 37(12): 5406-5420. doi:10.1016/j.jbankfin.2013.01.005.

Presidential Task Force on Market Mechanisms. 1988, Report of the Presidential Task Force on Market Mechanisms. Nicholas Brady (Chairman).

Raykov, Radoslav. 2012, "Reducing Margin Procyclicality at Central Counterparties." J. Finan. Market Infrastructures, 7(2): 43-59. doi:10.21314/JFMI.2018.106.

Schuermann, Til. 2014, “Stress Testing Banks." Int. J. Forecasting, 30(3): 717-728. doi:10.1016/j.ijforecast.2013.10.003.

Shleifer, Andrei, and Robert W. Vishny. 2011, "Fire Sales in Finance and Macroeconomics." J. Econ. Perspect., 25(1): 29-48. doi:10.1257/jep.25.1.29.

Sidanius, Che, and Filip Zikes. 2012, "OTC Derivatives Reform and Collateral Demand Impact." Technical report, Bank of England, URL https : / www . bankofengland . co . uk/ financial-stability-paper/2012/otc-derivatives-reform-and-collateraldemand-impact. Financial Stability Paper No. 18.

Tompaidis, Stathis. 2012, "Measuring System-wide Resilience of Central Counterparties." J. Finan. Market Infrastructures, 6(4): 41-54. doi:10.21314/JFMI.2018.098.

Valukas, Anton R., "Report of Examiner, United States Bankruptcy Court, Southern District of New York, in re. Lehman Brothers Holdings, Inc., et al., Chapter 11 case no. 08-13555." Jenner \& Block LLP, URL https : / /web . stanford . edu/ jbulow/Lehmandocs/menu . html. (Examiner's Report).

Wiggins, Rosalind Z., and Andrew Metrick. 2019, "The Lehman Brothers Bankruptcy G: The Special Case of Derivatives." J. Finan. Crises, 1(1): 151-171, URL https:// elischolar.library.yale.edu/journal-of-financial-crises/vol1/iss1/8.

Wong, Max, and Patrick Ge Pei. 2017, "Performance Testing of Margin Models Using Time Series Similarity." J. Finan. Market Infrastructures, 5(4): 51-75. doi:10.21314/JFMI.2017.076.

(Thomas King and Anna Paulson) Federal Reserve Bank of Chicago 230 S. LaSalle St., Chicago IL 60604

(Travis D. Nesmith and Todd Prono) Board of Governors of the Federal Reserve System 20TH \& C STs. NW, WASH. DC 20551

Email address, Thomas King: Thomas.King@chi.frb.org

Email address, Travis D. Nesmith: Travis.D.Nesmith@frb.gov

Email address, Anna Paulson: Anna.Paulson@chi.frb.org

Email address, Todd Prono: Todd.Prono@frb.gov 